\title{
The application of diatoms to reconstruct the history of subduction zone earthquakes and tsunamis
}

Tina Dura ${ }^{1,2} *$

Eileen Hemphill-Haley ${ }^{3}$

Yuki Sawai $^{4}$

Benjamin P. Horton ${ }^{1,2,5}$

${ }^{1}$ Sea Level Research, Department of Marine and Coastal Science, Rutgers University, New Brunswick, NJ, USA

${ }^{2}$ Institute of Earth, Ocean, and Atmospheric Sciences, Rutgers University, New Brunswick, NJ, USA

${ }^{3}$ Department of Geology, Humboldt State University, Arcata, CA, USA

${ }^{4}$ Geological Survey of Japan, National Institute of Advances Industrial Science and Technology (AIST), Tsukuba Central 7, 1-1-1 Higashi, Tsukuba, Ibaraki 305-8567, Japan

${ }^{5}$ Earth Observatory of Singapore and Asian School of the Environment, Nanyang Technological University, Singapore

*Corresponding Author: Tina Dura

Department of Marine and Coastal Science

Rutgers University

71 Dudley Road, New Brunswick, NJ 08901

Tel: +1 530.990.3468

Email: dura@marine.rutgers.edu

Keywords: Diatoms; earthquakes; tsunamis; subduction zones; sea level 


\section{Abstract}

Earthquake and tsunami records on centennial and millennial temporal scales are necessary to understanding long-term subduction zone behavior and the occurrences of large, but infrequent events. Microfossils, such as diatoms, incorporated into coastal stratigraphy provide some of the most detailed reconstructions of the history of earthquakes and tsunamis. We explore qualitative and quantitative techniques that employ the relation between diatoms and salinity, tidal elevation, and life form to: (1) reconstruct records of vertical land-level change associated with large earthquakes; and (2) identify anomalous sand and silt beds deposited by tsunamis. A global database shows that diatoms have been successfully employed in the reconstruction of earthquake and tsunami histories in Chile, the Indian Ocean, Japan, New Zealand, the North Sea, the Pacific Northwest of North America, and the South Pacific. We use case studies from some of these locations to highlight advancements in the field and new capabilities that diatoms have enabled. Examples from the Pacific Northwest of North America illustrate the evolution of quantitative diatom-based reconstructions of earthquake-related landlevel change. In Alaska and Japan, diatoms have documented land-level changes throughout the earthquake deformation cycle, including possible preseismic land-level change signals and postseismic deformation. Diatoms helped identify coseismic uplift along the central Chile subduction zone coast, and uplift and subsidence along the Alaska-Aleutian megathrust, expanding our knowledge of the variability of slip in megathrust ruptures. In tsunami studies, diatoms help determine the provenance of anomalous sands and silts found in low-energy coastal stratigraphic sequences. In Japan, allochthonous marine and brackish diatoms within sand deposits signaled repeated marine incursions into a coastal lake, helping identify a possible predecessor to the 2011 Tohoku tsunami. In the Pacific Northwest of North America and Chile, diatoms were used to estimate tsunami run-up beyond the landward limit of tsunami sedimentation. Examples from the North Sea, Thailand, and Japan show how the fragmentation and sorting of diatom valves may provide evidence of high-energy transport during the rapid, turbulent flow of a tsunami. To conclude, we emphasize the importance of studying the modern diatom response to changes in land level and/or tsunami inundation to improve diatom-based records of prehistoric earthquakes and tsunamis. 


\section{1. Introduction}

2 An incomplete understanding of the earthquake and tsunami hazards associated with

3 the Sunda and Japan subduction zones contributed to the devastating societal impacts of

4 the 2004 Indian Ocean and 2011 Tohoku events (Rhodes et al., 2006; Geller, 2011; Stein

5 and Okal, 2011; Heki, 2011). Instrumental records of previous earthquakes and tsunamis

6 proved too short to estimate the potential magnitude and recurrence interval of such great

7 events that recur centuries to millennia apart (Stein and Okal, 2007). With more than a

8 third of the world's coastlines lying adjacent to active plate boundaries (Lajoie, 1986;

9 Stewart and Vita-Finzi, 1998), we must extend earthquake and tsunami histories to

10 adequately assess hazards from subduction zones (Small et al., 2000; Satake and Atwater,

11 2007; Stein and Okal, 2011).

12 Stratigraphic evidence of subduction zone earthquakes and tsunamis has been used to

13 extend records over centuries to millennia. Stratigraphic evidence was first described

14 from the coastal wetlands of Alaska (Plafker, 1965; Plafker, 1972; Bartsch-Winkler and

15 Schmoll, 1987; Combellick, 1991, 1994; Combellick and Reger, 1994), the Pacific

16 Northwest of North America (Atwater, 1987; Darienzo and Peterson, 1990; Atwater

17 1992; Nelson, 1992; Darienzo et al., 1994; Nelson et al., 1996a), Chile (Wright and

18 Mella, 1963; Bourgeois and Reinhart, 1989; Atwater et al., 1992) and Japan (Kon'no,

19 1961; Minoura and Nakaya, 1991; Sawai et al., 2002; Nanayama et al., 2003; Sawai et

20 al., 2012, 2015). Subsidence or uplift associated with earthquakes is recorded as a series

21 of sharp stratigraphic contacts that reflect sudden changes in land level (Nelson et al.,

22 1996b; Yeats et al., 1997). Widespread sand beds, rapidly deposited by tsunamis

23 accompanying earthquakes, are often found concomitant with stratigraphic evidence of 
24 sudden land-level change (e.g., Hemphill-Haley et al., 1995a; Cisternas et al., 2005). In

25 addition, trans-oceanic tsunamis produced by the largest subduction zone earthquakes can

26 deposit sediments on coastlines hundreds to thousands of kilometers away from the

27 earthquake source (e.g., Satake et al., 1996; Goff et al., 2006).

28 Microfossils such as diatoms, foraminifera, and pollen that are incorporated into

29 coastal stratigraphy provide qualitative and quantitative estimates of land-level change

30 associated with subduction zone earthquakes (Horton et al., 2013; Fig. 1). In particular,

31 diatoms and foraminifera have been applied to earthquake and tsunami studies around the

32 world (e.g., Darienzo et al., 1994; Hemphill-Haley, 1995a, 1995b, 1996; Sawai et al.,

33 2004a, b; Shennan and Hamilton, 2006; Hawkes et al., 2011; Engelhart et al., 2013;

34 Grand Pre et al., 2012; Clark et al., 2015; Dura et al., 2015). These microfossils have

35 improved upon early coastal studies of subduction-zone earthquake history that estimated

36 the amount of coseismic land-level change with large errors (>1 m) based on the broad

37 elevational ranges of plant macrofossils (Atwater, 1987, 1992; Clague and Bobrowsky,

38 1994). Quantitative diatom and foraminiferal-based reconstructions of land-level change

39 (e.g., transfer functions) can produce substantially smaller $(<0.3 \mathrm{~m})$ errors (Guilbault et

40 al., 1995, 1996; Zong et al., 2003; Sawai et al., 2004a,b; Shennan and Hamilton, 2006;

41 Nelson et al., 2008; Hawkes et al., 2011; Engelhart et al., 2013; Watcham et al., 2013).

42 Microfossils are applied to tsunami studies to determine the provenance of tsunami

43 sediments deposited in low-energy coastal environments such as lowlands (Hemphill-

44 Haley, 1995a, 1996; Benson et al., 1997; Nanayama et al. 2007; Sugawara et al., 2009),

45 interdunal depressions (Dawson and Stewart, 2007; Jankaew et al., 2008), lagoons

46 (Minoura and Nakaya, 1991; Nichol et al., 2007; Sawai et al., 2009b; Wilson et al., 2014) 
47 and lakes (Hutchinson et al., 1997; Grauert et al., 2001; Kelsey et al., 2005).

48 Allochthonous marine assemblages or a chaotic mix of marine, brackish and freshwater

49 taxa within terrestrial or brackish settings may be indicative of marine incursions from

50 tsunamis (Tuttle et al., 2004; Cochran et al., 2005; Hawkes et al., 2007; Goff et al., 2012;

51 Clark et al., 2015), and the preservation and distribution of diatoms and foraminifera

52 throughout the deposit can be used to infer high-energy transport and provenance

53 (Hemphill-Haley, 1996; Sawai et al., 2002; Pilarczyk et al., 2012a).Tsunamis of the past

54 two decades have provided an opportunity to characterize the microfossil composition of

55 modern deposits (Dawson, 2007; Sawai et al., 2009a; Chagué-Goff et al., 2011;

56 Szczuciński et al., 2012b), improving our ability to identify such characteristics in the

57 fossil record.

58 In this review we explore the application of diatoms to earthquake and tsunami

59 studies (Fig. 2; Table 1). We explain the statistical approaches that use diatoms to

60 estimate earthquake related land-level changes, and assess the utility of diatoms in

61 identifying tsunamis in the stratigraphic record. We also examine the knowledge gaps

62 and limitations of diatom analyses in earthquake and tsunami studies, and make

63 recommendations for future research.

\section{2. Reconstructing coastal environments with diatoms}

65 Diatoms are photosynthetic, unicellular algae that inhabit freshwater, brackish, and 66 marine environments (Round et al., 1990; Jones, 2007). Diatoms are a dominant

67 microphyte in coastal wetland environments and their siliceous valves, ranging in size

68 from $\sim 5 \mu \mathrm{m}$ to $\sim 200 \mu \mathrm{m}$, are resistant to taphonomic degradation (e.g., dissolution,

69 abrasion, bioerosion, oxidation, transport, predation; Admiraal, 1984; Palmer and Abbott, 
70 1986; Cooper et al., 2010). As a result, small (1 $\mathrm{g}$ wet weight) sample sizes (for example,

71 from narrow-diameter cores $25-50 \mathrm{~mm}$ ) contain statistically significant (300-600 valves)

72 diatom populations (Birks, 1995; Battarbee et al., 2001; Nelson, 2015).

73 Diatoms have been described and classified for over 200 years based on their shapes,

74 sizes, and the intricate morphological characteristics of their siliceous valves (Round et

75 al., 1990). Diatom taxa are divided into three main classes: the Coscinodiscophyceae

76 (centric taxa); Fragilariophyceae (araphid pennate taxa); and Bacillariophyceae (raphid

77 pennate taxa). Literature on the identification of diatoms to species level includes van der

78 Werff and Huls (1958-1974), Patrick and Reimer (1966, 1975), Krammer and Lange-

79 Bertalot (1986, 1988, 1991a, b), Hartley et al. (1996), Krammer (2000, 2002, 2003),

80 Lange-Bertalot (2000, 2001, 2011), and Levkov (2009).

81 Diatoms are a valuable tool in reconstructing paleoenvironmental changes because

82 of their sensitivity to environmental factors including salinity, tidal exposure, substrate,

83 vegetation, $\mathrm{pH}$, nutrient supply, and temperature found in specific coastal wetland

84 environments (e.g., Zong and Horton, 1998). Over time, diatoms become incorporated in

85 coastal sediments, resulting in buried assemblages that represent an environmental

86 history that can span thousands of years. Literature for the ecological classification of

87 diatoms includes Hustedt (1937, 1939, 1953, 1957), Lowe (1974), Patrick and Williams

88 (1990), Denys (1991-1992), Juggins (1992), Vos and de Wolf (1988; 1993), Van Dam et

89 al. (1994), and Lange-Bertalot (2000).

90 Diatoms' preferences for salinity are valuable for earthquake and tsunami studies.

91 Changes in salinity across the intertidal zone produce vertically zoned diatom

92 assemblages with respect to the tidal frame (Nelson and Kashima, 1993; Hemphill-Haley 
93 1995b; Sherrod et al., 1999; Patterson et al., 2005; Horton and Sawai, 2010; Woodroffe

94 and Long, 2010). Establishing the distribution of diatoms across the intertidal zone is a

95 prerequisite for reconstructing paleoenvironmental changes related to earthquakes and

96 tsunamis (e.g., Zong and Horton, 1998). In the halobian classification scheme,

97 polyhalobous and mesohalobous diatom taxa represent the marine and brackish

98 conditions found in tidal flats and lower tidal marshes and mangroves. Oligohalobous-

99 halophile and oligohalobous-indifferent taxa become dominant through the transition

100 from tidal marsh/mangrove to freshwater environments, and halophobous taxa

101 characterize the most landward freshwater communities above the highest tides. The

102 presence of diatoms in freshwater environments is an obvious advantage compared to

103 foraminifera, which are restricted to areas of marine influence (e.g., Murray, 1991).

104 The distribution of diatoms along a modern intertidal transect (Fig. 3) typically

105 shows a clear transition from subtidal, open-water marine diatoms (e.g., Thalassiosira

106 pacifica and Odontella aurita), to marine tidal flat taxa (e.g., Achnanthes brevipes and

107 Tabularia fasciculata). In the low marsh, where a mixed diatom community is often

108 found, marine-brackish diatoms (e.g., Planothidium delicatulum and Tryblionella

109 granulata) dominate, followed by freshwater taxa that can tolerate low salinities in the

110 high marsh (e.g., Caloneis bacillum and Cosmioneis pusilla) and freshwater salt-

111 intolerant taxa in the upland environment (e.g., Eunotia bilunaris and Aulacoseira

112 crassipunctata).

113 The distribution of diatoms across the intertidal zone based on their life form is

114 valuable for tsunami studies. The diverse life forms of diatom floras are employed to

115 support the marine provenance of inferred tsunami deposits. Hustedt (1958), Vos (1986), 
116 Vos et al. (1988), and Vos and de Wolf (1993) define diatom life forms based on the

117 substrate - or lack thereof - that particular diatom taxa commonly live on. Benthic

118 diatoms are grouped into epipsammic taxa that live attached to sand grains; epipelic taxa

119 that live on or just below the surface of wet muddy sediment; epiphytic taxa that are

120 attached to larger plants or other surfaces; and aerophile taxa that are able to survive

121 subaerial, temporarily dry conditions. Planktonic diatoms float freely in the water column

122 and do not live attached to any substrate; tychoplanktonic diatoms include an array of

123 species that live in the benthos, but are commonly found in the plankton. Based on local

124 conditions, epipsammic, epipelic, planktonic, and tychoplanktonic diatoms may comprise

125 tidal flat populations, whereas epiphytic and epipelic forms are more common on tidal

126 marshes/mangroves. Aerophilous forms are most common within the landward

127 communities above the highest tides (Sherrod, 1999).

\section{3. Application of diatoms to subduction zone paleoseismic cycles}

\subsection{Earthquake deformation cycle}

130 On subduction zone coastlines, the land-level changes associated with earthquakes

131 reflect the strain accumulation and release of the earthquake deformation cycle (Burbank

132 and Anderson, 2001; Nelson, 2013). The nature of the interseismic and coseismic motion

133 of the coastline is determined by its proximity to the trench, the geometry of the

134 subduction zone, and where ruptures stop along strike (Plafker, 1965; Plafker and

135 Savage, 1970; Wang et al., 2012). Some subduction zone coastlines (e.g., Cascadia, the

136 Pacific Northwest of North America) lie within a zone that gradually uplifts in between

137 (interseismic) and abruptly subsides during (coesismic) great earthquakes (Plafker, 1972,

138 Atwater 1987). In coastal wetland stratigraphy, the interseismic period is represented by a 
139 gradual regression from clastic (e.g., tidal flat or shallow subtidal) to organic-rich (e.g.,

140 marsh or swamp) sediments reflecting land-level uplift (i.e., relative sea-level fall) and a

141 decrease in marine influence. Abrupt coseismic land subsidence creates a sudden change

142 from organic-rich sediments to clastic sediments, reflecting land-level subsidence (i.e.,

143 relative sea-level rise) and an increase in marine influence (Fig. 1).

144 Conversely, some coastal locations bordering subduction zones (e.g., central Chile;

145 Alaska-Aleutian megathrust) lie within a zone that gradually subsides in between and

146 abruptly uplifts during great earthquakes (Shennan et al., 2009; Dura et al., 2015). During

147 the interseismic period, coastal wetland stratigraphy displays a gradual transgression

148 from organic-rich to clastic sediments as land-level subsides and marine influence

149 increases. Abrupt coseismic uplift creates a sudden change from clastic to organic-rich

150 sediments, reflecting land-level uplift and a decrease in marine influence.

151 Coastal wetland stratigraphy can record both coseismic uplift and subsidence at one

152 location (e.g., Hayward et al., 2006; Briggs et al., 2014; Ely et al., 2014), depending on

153 the distribution of slip upon the megathrust surface (Savage and Hastie, 1966) or the

154 interaction with upper plate faults. The possibility of a variable uplift-subsidence history

155 illustrates that the paleoseismic record should not be assumed to record exclusively

156 coseismic uplift or subsidence.

157 Because non-seismic coastal processes can also produce changes in stratigraphy

158 similar to those created by great subduction zone earthquakes, criteria must be considered

159 to support a tectonic origin (Darienzo et al., 1994; Nelson et al., 1996b; Shennan et al.,

160 1996; Dura et al., 2015). The key criteria are the lateral extent of sharp stratigraphic

161 contacts; the suddenness and magnitude of land-level change; the synchroneity of land- 
162 level change among regional sites; and the coincidence of tsunami deposits with sudden

163 changes in stratigraphy. No breaks in sedimentation greater than a few weeks are

164 assumed to occur following earthquake-related land-level change and continuous

165 sedimentation is assumed in the interseismic period. Although many paleoseismic studies

166 have relied on stratigraphic investigations to support an earthquake origin (Atwater,

167 1987; Dura et al., 2011), microfossils have been particularly useful in providing

168 supporting evidence of earthquake-related land-level change.

\subsection{Diatoms and land-level changes related to the earthquake deformation cycle}

170 Much of the early research using diatoms to reconstruct land-level changes related to

171 the earthquake deformation cycle focused on the Pacific Northwest of North America

172 (Cascadia subduction zone). Regional sea-level rise at rates of up to $2 \mathrm{~mm} / \mathrm{yr}$ along the

173 central Cascadia subduction zone since 6,000 calibrated years BP (Engelhart et al., 2015)

174 resulted in continuous records of tidal sedimentation that contain evidence of coseismic

175 land-level change and tsunami inundation.

176 Darienzo and Peterson (1990) and Darienzo et al. (1994) employed qualitative

177 diatom analyses to confirm inferences of sudden and widespread coseismic subsidence

178 based on distinctive stratigraphic contacts in Cascadia coastal wetlands. Darienzo et al.

179 (1994) used diatoms to identify broad floral zones (e.g., high marsh, low marsh, tidal flat)

180 in the modern environment and subsequently estimated the magnitude of coseismic

181 subsidence by identifying analogous floral zones from above and below sharp

182 stratigraphic contacts. Because the elevational range of the floral zones was large (0.5-1.0

$183 \mathrm{~m}$ ), errors for subsidence estimates commonly exceeded $1 \mathrm{~m}$ (e.g., Nelson and Kashima, 
184 1993; Darienzo and Peterson, 1990; Darienzo et al., 1994; Kelsey et al., 2002; Witter et 185 al., 2003).

186 Statistical methods employed the relationship between modern diatom assemblages 187 of known elevation and fossil assemblages to reconstruct land-level changes in 188 stratigraphic sections at Cascadia (Hemphill-Haley, 1995a; Nelson et al., 1996a; Shennan 189 et al., 1996). In southern Washington State, USA, Hemphill-Haley (1995b) used factor 190 analysis to identify the relation of modern diatom distributions to elevation. The result 191 was a list of taxa with dominant occurrences in marsh zones (high marsh, low marsh, and

192 high and low marshes) and three subenvironments of the lower intertidal to shallow 193 subtidal zone (mud flats, sand flats, and Zostera (eelgrass) beds). The modern

194 distributions of the same taxa found in the fossil record were used to reconstruct the 195 abrupt changes in environment indicated by stratigraphic contacts spanning the AD 1700 196 subduction zone earthquake (Fig. 4). Distinct changes in diatom assemblages across these 197 sharp contacts confirmed significant, widespread, and lasting change from an upland 198 environment to a tidal-flat or low marsh environment, consistent with coseismic 199 subsidence of 0.8-1.1 m. Shennan et al. $(1996,1998)$ and Nelson et al. (1996a) employed 200 similar statistical techniques (i.e., ordination and discriminant function analysis, 201 respectively) to quantitatively compare modern diatom assemblages of known elevation 202 with fossil diatom assemblages. Although the statistical techniques of Hemphill-Haley 203 (1995b), Shennan et al. (1996, 1998), and Nelson et al. (1996a) improved the analysis of 204 diatom data, the reconstructions were still based on differences in elevational ranges 205 between pre-earthquake and postearthquake paleoenvironments, resulting in $0.5-1.0 \mathrm{~m}$ 206 errors. 
Fully quantitative, microfossil-based transfer functions used to calculate coseismic

208 land-level change at Cascadia have produced substantially smaller errors $(<0.5 \mathrm{~m}$; e.g.,

209 Guilbault et al., 1995, 1996). The transfer function uses multivariate statistical techniques

210 to formalize the relationship between the relative abundance of microfossil species and

211 the environmental variable of interest (in the case of paleoseismic studies, that variable is

212 elevation; e.g., Horton et al., 1999). The transfer function is applied to microfossil

213 assemblages in coastal wetland stratigraphic sequences to calculate changes in paleo-

214 elevation and can provide a continuous record of land-level changes throughout the

215 earthquake deformation cycle. The performance of transfer functions can be measured

216 using multiple techniques to assess the effect of sample design, the goodness-of-fit

217 between microfossil assemblages and elevation, and the statistical significance of each

218 reconstruction (Telford and Birks, 2011a, b). The technique has since been expanded in

219 Cascadia to include extensive modern diatom (Sherrod, 1999, 2000, 2001), foraminifera

220 (Guiltbault et al., 1995, 1996; Hawkes et al., 2010; Engelhart et al., 2013), and pollen

221 (Hughes et al., 2002) datasets, and applied in other geographical locations such as Alaska

222 (e.g., Shennan and Hamilton, 2006), Japan (e.g., Sawai, 2004b), and Chile (e.g., Garrett

223 et al., 2014; Table 1 lists which diatom studies have used quantitative diatom techniques,

224 Fig. 2).

225 Coastal wetland stratigraphy from eastern Hokkaido, Japan contains evidence of 226 preseismic and postseismic land-level change (Atwater et al., 2004; Sawai et al., 2002,

$2272004 \mathrm{a}, \mathrm{b}$ ) associated with subduction zone earthquakes originating from the Kuril Trench

228 (Nanayama et al., 2003). Sawai et al. (2004a) used a diatom-based transfer function

229 (Sawai et al., 2001b, 2004b) to document the land-level change associated with a great 
$23017^{\text {th }}$ century earthquake and tsunami (Fig. 6). Fossil diatom assemblages show that tidal

231 flats gradually changed into freshwater upland environments in the decades after the

232 earthquake as a result of up to $1.5 \mathrm{~m}$ of postseismic uplift. Sawai et al. (2004a) suggested

233 the large land-level change was the result of a subduction zone earthquake of unusually

234 large size along the Kuril Trench.

235 Diatom data have helped identify coseismic uplift associated with subduction zone 236 earthquakes in Alaska (e.g., Shennan et al., 2009, 2014) and Chile (e.g., Dura et al., 237 2015). Along the central Chile coast, Dura et al. (2015) used diatoms to identify six 238 instances of cosesimc uplift between 6200 and 3600 calibrated years BP. A repeated 239 influx of freshwater diatoms and other siliceous microfossils above six tsunami sands 240 suggested $>1 \mathrm{~m}$ of coseismic uplift. The study documented a $\sim 500$ year recurrence 241 interval for the earthquakes and accompanying tsunamis in central Chile.

242 Diatom studies have documented evidence of both coseismic subsidence and uplift at 243 the same site. Briggs et al. (2014) used diatoms and foraminifera to identify five instances 244 of sudden uplift and subsidence in the stratigraphy of a coastal marsh on Sitkinak Island 245 bordering the Alaska-Aleutian megathrust. Diatoms showed uplift accompanying 246 earthquakes in 290-0, 520-300, and 1050-790 calibrated years BP, and subsidence in AD

2471964 and 640-510 calibrated years BP (Briggs et al., 2014). Such studies have 248 implications for seismic hazard analysis, as the mixed uplift and subsidence record shows 249 the variability of slip along the megathrust, suggesting that the segmentation of 250 subduction zones is not fixed (Briggs et al., 2014; Ely et al., 2014).

251 Diatom data have also identified a possible preseismic signal from relatively small 252 amounts of land-level change in the years prior to earthquakes (Bourgeois, 2006; 
253 Shennan and Hamilton, 2006). Zong et al. (2003) used detailed modern and fossil diatom

254 analyses from a coastal wetland along the eastern Alaska-Aleutian megathrust to

255 reconstruct preseismic and coseismic land-level changes associated with the AD 1964

256 Alaska earthquake. In the 15 years prior to the AD 1964 earthquake, diatoms showed a

257 gradual shift from a freshwater environment dominated by salt-intolerant taxa (e.g.,

258 Eunotia exigua, Eunotia pectinales, and Achnanthes minutissima) to salt-tolerant

259 freshwater taxa typical of a high marsh environment (e.g., Navicula pupula, Nitzschia

260 fruticosa, and Pinnularia lagerstedtii). Zong et al. (2003) interpret the shift in diatom

261 assemblages as a phase of gradual land subsidence of $\sim 0.15 \mathrm{~m}$ that preceded up to $2 \mathrm{~m}$ of

262 coseismic subsidence in the AD 1964 earthquake. If preseismic deformation does occur,

263 the implication is that warning signs may be detectable for several years prior to a great

264 earthquake (Bourgeois, 2006).

265 Hamilton et al. (2005) explored whether the preseismic signal was a result of mixing

266 of diatom assemblages from biological or physical processes. Hamilton et al. (2005)

267 transplanted a block of marsh peat to a lower elevation in the intertidal zone where it

268 would be buried by tidal mud. The results showed that mixing of diatoms did occur, but

269 only in the top $\sim 1 \mathrm{~cm}$ of peat, whereas the preseismic signal observed by Zong et al.

270 (2003) and Hamilton and Shennan (2005b) occurred over 2-5 cm. In addition, Shennan

271 and Hamilton (2006) argued that the preseismic signal was not a result of diatoms

272 filtering down from overlying mud because dominant species that reflect subtle

273 preseismic subsidence, such as Nitzschia obtusa, Navicula begeri, Navicula brockmanii,

274 and Pinnularia lagerstedtii, do not occur in the overlying mud (Fig. 5). A similar

275 transplant experiment at Cascadia found that mixing of foraminifera did occur up to $3 \mathrm{~cm}$ 
276 below the transplanted marsh peat surface, mimicking a preseismic signal (Engelhart et

277 al., 2013). Englehart et al. (2013) cautioned against interpreting microfossil assemblages

278 in such mixed layers as a preseismic signal.

\section{4. Application of diatoms to tsunami studies}

\subsection{Paleotsunamis}

Sequences of tsunami deposits preserved along subduction zone coastlines can be

282 used to estimate recurrence intervals of tsunamigenic earthquakes over centuries to 283 millennia (Nanayama et al., 2003; Cisternas et al., 2005; Jankaew et al., 2008; Sawai et 284 al, 2012). Stratigraphic sequences, supported by diatom studies, reveal repeated tsunamis 285 in numerous locations including Alaska, the Pacific Northwest of North America, Chile, 286 Japan, New Zealand, and locations bordering the North Sea and the Indian Ocean (Table 287 1, Fig. 2).

288 Allochthonous marine and brackish diatoms within tsunami deposits, including 289 benthic and planktonic taxa, can support a seaward provenance of the sediment (e.g., 290 Hemphill-Haley, 1995a; Sawai, 2002; Dura et al., 2015). Diatom analysis helped identify 291 the provenance of three sand beds recovered from a coastal lake at Suijin-numa, on the 292 subduction zone of the Japan Trench (Sawai et al., 2008). The marine and brackish 293 diatoms (Diploneis smithii, Delphineis surirella) within the sand beds contrasted against 294 the freshwater assemblages (Aulacoseira granulata, A. crassipunctata, Eunotia spp.) in 295 the under and overlying mud. The middle sand bed at Suijin-numa correlates with the 296 Jogan earthquake in AD 869 (Yoshida, 1906), the presumed predecessor to the 2011

297 Tohoku earthquake. Along the Kuril Trench in northern Japan, Nanayama et al. (2007) 298 used diatoms to identify nine sandy tsunami deposits intercalated with peat. The diatom 
assemblage within the peats contained freshwater species (e.g., Eunotia spp., Pinnularia

300 spp.), whereas the sand beds were dominated by marine taxa (e.g., Delphineis surirella

301 and Odontella aurita). Based on the record of tsunami deposits, the authors estimated a

$302365-553$ year recurrence interval for large Kuril Trench earthquakes. Later, based on

303 over 60 radiocarbon age estimates, Sawai et al. (2009b) found that the interval between

304 tsunamis on the Kuril Trench ranged from 100 to 800 years, with an average recurrence

305 interval of $\sim 400$ years.

306 In the Storegga Slide tsunami ${ }^{1}$ deposits in Scotland, Dawson et al. (1996a) found an

307 anomalous marine diatom assemblage with a high occurrence of fragmented diatoms. Up

308 to $90 \%$ of valves (60\% of which have elongate forms) within the sand bed were

309 fragmented, reflecting the nature of the rapid, turbulent marine incursion of tsunami

310 events (Dawson et al., 1996a; Smith et al., 2004; Fig. 7). Similar preferential

311 fragmentation of diatom valves, in particular elongate forms $(>100 \mu \mathrm{m})$ has been

312 documented in inferred paleotsunami deposits in the Pacific Northwest of North America

313 (Witter et al., 2009) and Japan (Sawai, 2002). Conversely, anomalously low breakage of

314 diatoms in tsunami deposits has been reported in paleotsunamis from the Pacific coast of

315 Washington State and Puget Sound, USA (Hemphill-Haley, 1996). Hemphill-Haley

316 (1996) suggested that the low breakage of diatoms reflects rapid sedimentation by the

317 tsunamis.

318 Diatoms can be used to estimate tsunami run-up beyond the landward limit of

319 tsunami deposits. Hemphill-Haley (1996) used the distribution of diatoms to show that

320 the inundation area of the tsunami from the AD 1700 Cascadia subduction zone

${ }^{1}$ The Storegga Slide tsunami ( 7900 calibrated years BP) was produced by a submarine landslide (Bondevik et al., 2005). 
321 earthquake was larger than the distribution inferred from the coarser-grained deposit

322 visible in outcrop. Epipsammic tidal flat diatoms were found about $1 \mathrm{~km}$ farther upstream

323 from the landward extent mapped in cores and stream channel outcrops.

\subsection{Tsunamis of the past two decades}

325 Diatom analysis of recent tsunami deposits provides modern analogues for 326 reconstructing the fossil record. Recent studies characterized the diatom composition of

327 the 1998 Papua New Guinea (Dawson, 2007), 2004 Indian Ocean (Sawai et al., 2009a;),

3282009 South Pacific (Chagué-Goff et al., 2011), 2010 Maule Chile (Horton et al., 2011;

329 Garrett et al., 2013), and 2011 Tohoku (Szczuciński et al., 2012b; Sawai et al., 2012)

330 tsunamis. Analyzing the diatom signature of recent tsunamis can be used to infer the

331 sedimentation (e.g., high-energy deposition), sediment provenance, and inundation limits

332 of the events.

333 The taphonomy of diatom valves may indicate the mode of sedimentation of a

334 tsunami. Dawson (2007) explored the condition of diatom valves in the 1998 Papua New

335 Guinea tsunami deposit and found that linear, sigmoid, and clavate diatoms were more

336 readily fragmented during the high-energy tsunami due to their relatively fragile valve

337 structure. In contrast, high abundances of taphonomically unaltered (i.e., pristine) diatom

338 valves were found in tsunami deposits from the 2004 Indian Ocean tsunami in Thailand

339 (Sawai et al., 2009), and the 2010 Maule tsunami in Chile (Horton et al., 2011).

340 The upward fining of grain size observed in tsunami sands may be reflected by

341 similar grading of diatom valves, a result of the variable flow speed of a tsunami

342 (Gelfenbaum and Jaffe, 2003). In Thailand, the 2004 Indian Ocean tsunami deposit

343 consisted of a sand bed with a thin mud cap and contained mostly beach and subtidal 
344 diatoms (>80\%) and very few freshwater species (Fig. 8; Sawai et al., 2009a). The lower

345 section of the deposit was dominated by larger epipsammic marine diatoms, whereas the

346 middle section contained abundant marine planktonic species, and the mud cap was

347 dominated by a mixture of smaller freshwater, brackish, and marine species. Diatom

348 analysis by Chagué-Goff et al. (2011) following the 2009 South Pacific tsunami deposit

349 in Samoa, Horton et al. (2011) following the 2010 Maule tsunami in Chile, and

350 Szczuciński et al. (2012b) following the 2011 Tohoku-Oki tsunami on the Sendai plain

351 also revealed grading of diatom valves.

352 Diatoms recovered from tsunami deposits perpendicular to the coast show variable

353 concentration, ecology, and taphonomy related to the provenance of material.

354 Szczuciński et al. (2012b) found that within $1 \mathrm{~km}$ of the coast, the Tohoku-Oki sand beds

355 were derived mainly from the beach and coastal dunes, and because such sediments were

356 devoid of diatoms, the assemblage within the tsunami sediments was composed of a low

357 concentration of fragmented freshwater and few brackish species sourced from the

358 coastal plain. Further inland the diatom concentration within the tsunami sediments

359 increased, and the assemblage and condition of valves in the deposit ( $\%$ fragmentation of

360 valves) were very similar to the valves in the underlying soil and nearby freshwater canal,

361 suggesting that the sediment was locally sourced and not transported from the coast

362 (Szczuciński et al., 2012b).

363 Chagué-Goff et al. (2015) used the diatom assemblages of the 2010 Maule Chile

364 tsunami deposit to trace tsunami inundation beyond the limit of sedimentological

365 evidence. Marine diatoms could be traced $\sim 100 \mathrm{~m}$ beyond the inundation limit identified

366 by the tsunami deposit. 


\section{Knowledge gaps}

368 Diatoms have improved our understanding of the nature of land-level change 369 associated with past earthquakes and have helped define the impacts of past tsunamis.

370 However, when using diatoms for reconstructing earthquake-related land-level change 371 and tsunami inundation, several matters must be kept in mind.

\subsection{Uncertainties in modern diatom distributions}

373 An absence of local to regional modern diatom datasets from a range of coastal 374 environments restricts the application of diatoms to reconstruct the history of subduction

375 zone earthquakes and tsunamis. The relation of diatoms to tidal elevation is unknown in 376 many locations because of a scarcity of modern data (e.g., Dura et al., 2015). However,

377 even modern diatom data sets that include hundreds of samples taken across multiple 378 local coastal wetlands can fail to provide modern analogues for fossil diatom assemblages

379 (Watcham et al., 2013). This non-modern-analogue situation (Birks, 1995) is attributed to

380 local environmental conditions having changed significantly over time (Watcham et al., 381 2013). If this happens, it is not appropriate to apply quantitative reconstruction techniques 382 (e.g., transfer function) using only local modern diatom assemblages (Watcham et al., 383 2013). Regional modern training sets compiled from a large range of intertidal coastal 384 environments (e.g. marshes with a variety of vegetation zones, substrates, and elevation 385 gradients) can account for such variation in the distribution of diatoms, providing analogs 386 for diatom assemblages found in fossil cores (Zong et al., 2003; Watcham et al., 2013; 387 Shennan et al., 2014a). 
390 across sharp stratigraphic contacts, a possible delay in sediment deposition and diatom

391 response must be considered. If there is a significant (months to years) hiatus in response

392 following an earthquake, estimates of coseismic deformation will include both coseismic

393 and postseismic deformation, thus they will be minimum estimates (Garrett et al., 2013).

394 Shennan et al. (2014a) found that peat formation following the coseismic uplift of an

395 intertidal mudflat along the eastern Alaska-Aleutian megathrust was not instantaneous,

396 resulting in minimum estimates of uplift. The study also found a mixed salinity diatom

397 assemblage in the upper part of the buried silt that formed as a result of ponding and

398 reworking of the uplifted surface before colonization by terrestrial plants, and likely did

399 not represent the pre-earthquake environment and elevation. In Chile, Garrett et al.

400 (2013) found that uplifted marshes had accumulated little to no sediment up to two years

401 after the 2010 earthquake and tsunami, complicating estimates of coseismic uplift.

402 Coseismic subsidence more often results in rapid sedimentation of clastic sediments

403 hours to weeks after an earthquake, due to the accommodation space created in the 404 submerged marsh (Atwater et al., 2001; Hawkes et al., 2011).

\subsection{The production and preservation of diatoms}

406 Diatom-based reconstructions of earthquake-related land-level change and tsunami 407 inundation are hindered by variable diatom production and preservation. In the Copper 408 River Delta, Shennan et al. (2014a) found low numbers of diatoms in modern samples 409 taken from tidal flat silts, a result of high sediment accretion of the delta environment. 410 Silts in fossil sequences also contained few diatoms, which complicated quantitative 
411 reconstructions of earthquake-related land-level change (Shennan et al., 2014a). In

412 relatively alkaline and warm environments, there are problems with chemical dissolution

413 of diatom valves (Katamani, 1982; Flower, 1993; Barker et al., 1994). Sawai et al.

414 (2009a) found excellent preservation of diatoms in the 2004 Indian Ocean tsunami

415 deposit in Thailand, but three paleotsunami deposits examined at the same site by

416 Jankeaw et al. (2008) contained no fossil diatoms. Dissolution of diatom valves can also

417 make them more susceptible to fragmentation, complicating the use of the fragmentation

418 metric to infer high-energy deposition during a tsunami. Szczuciński et al. (2012b) found

419 a similar degree of fragmentation in diatoms within the soil underlying the 2011 tsunami

420 deposit and within the deposit itself.

\section{$421 \quad 5.4$ Differentiating autochthonous and allochthonous diatoms}

422 Problems differentiating autochthonous (in situ) and allochthonous (transported)

423 diatoms in modern and fossil studies complicate reconstructions. Certain taxa are

424 transported across coastal wetlands and, if included in modern or fossil assemblages,

425 erroneously represent the depositional environment. This problem is common in coastal

426 wetlands where diatom valves are transported from one intertidal floral zone to another

427 by daily tidal currents, or, in colder climates, by ice rafted sediment (Hemphill-Haley et

428 al., 1995a; Hamilton et al., 2005). Hemphill-Haley (1995a) and Sawai (2001b, 2004)

429 suggested several means to distinguish allochthonous diatoms in both modern and fossil

430 assemblages. Planktonic diatoms are considered allochthonous components in modern

431 and fossil coastal wetland assemblages, while benthic taxa (e.g., epiphytic, epipelic and

432 epipsammic types) can be considered as autochthonous (Vos and de Wolf, 1993). Some

433 chain-forming taxa with thickly silicified valves may form prominent allochthonous 
434 assemblages. Hemphill-Haley (1995a) excluded the marine tychoplanktonic diatom

435 Paralia sulcata from paleoecological interpretations, because its robust valves and long-

436 chained structure allow its valves to be easily floated and transported by tidal currents

437 and deposited far inland in tidal estuaries (Hemphill-Haley, 1995a). Sawai (2001b,

438 2004b) recognized allochthonous distributions of certain epiphytic taxa in the intertidal

439 zone. For example, Cocconeis scutellum is an epiphytic species commonly found

440 attached to macrophytes in the intertidal zone. After death, the upper (rapheless) valve

441 that is not attached to the macrophyte may detach and be transported by tidal currents

442 (Sawai, 2004b). As a result, rapheless valves of $C$. scutellum may be found in sediment

443 across the entire intertidal zone, although its habitat is limited to the macrophyte zone

444 (Sawai, 2001b).

$445 \quad 5.5$ Differentiating tsunami and storm surge deposits

446 Allochthonous marine and brackish diatoms may be found in storm-surge deposits,

447 making it difficult to differentiate from tsunami deposits in the stratigraphic record (e.g.

448 Liu and Fearn, 2000; Parsons, 1998; Tuttle et al., 2004; Horton et al., 2009). However,

449 coseismic land-level change coincident with anomalous silt and sand beds provides a

450 definitive earthquake source for a tsunami. In Washington State, USA Hemphill-Haley

451 (1995a) identified two coarse-grained silt and sand beds dominated by marine diatoms. A

452 tsunami source was inferred from one bed because it was associated with a sudden

453 change in depositional environment from upland soil to intertidal mud, consistent with

454 coseismic submergence. The other bed within a freshwater upland soil was not associated

455 with a change in stratigraphy and was probably deposited by a storm (Hemphill-Haley,

456 1995a). 


\section{Conclusions}

458 Using global examples, we illustrated the utility of diatoms in reconstructing land-

459 level change and tsunami inundation histories along subduction zone coastlines on

460 centennial and millennial timescales. We outlined the evolution of fully quantitative,

461 statistical techniques to estimate coseismic land-level change at the Cascadia subduction

462 zone. Examples from the Alaska-Aleutian megathrust and the Japan trench illustrated the

463 expanded application of the transfer function technique to reconstruct preseismic,

464 coseismic, and postseismic land-level change. In central Chile, diatoms were successfully

465 applied to identify coseismic uplift, and in Alaska, diatoms helped reconstruct a mixed

466 uplift and subsidence record preserved in coastal wetland stratigraphy.

467 We illustrated the utility of diatoms in inferring the sediment provenance, 468 sedimentation, and inundation limit of tsunamis. Allochthonous marine and brackish 469 diatoms within anomalous sand beds along the coasts of Japan, Scotland, and Thailand

470 indicate a seaward provenance of sediments, supporting a tsunami source. The high

471 fragmentation of diatom valves in sand beds deposited by the Storegga tsunami and the

4721998 Papua New Guinea tsunami reflect high-energy sedimentation, while the upward

473 fining of diatom valves in the 2004 Indian Ocean tsunami reflect the variable flow speed

474 of a tsunami. Examples from the Cascadia subduction zone and the Chile subduction

475 zone showed diatoms how can be used to estimate tsunami run-up beyond the landward

476 limit of tsunami deposits, a powerful tool in estimating paleotsunami inundation.

477 We outlined a series of knowledge gaps that should be considered in future research.

478 Many of the knowledge gaps in the study of diatom-based earthquake and tsunami

479 records can be addressed by continuing to explore the modern diatom environments, in 
particular exploring diatoms' relation to salinity and substrate, variable production,

481 preservation, and transport. Examining the response of diatoms to recent earthquake-

482 related land-level change and the character of modern tsunami deposit diatom

483 assemblages will continue to provide analogues for identifying events in the fossil record.

\section{Acknowledgements}

This work was supported by funding from the National Science Foundation grant

Alan Nelson for constructive reviews that substantially improved the manuscript.

\section{References}

Admiraal, W., 1984. The ecology of estuarine sediment-inhabiting diatoms. Progress in

Amspoker, M.C., McIntire, C.D., 1978. Distribution of diatoms associated with sediments in Yaquina Estuary, Oregon. Journal of Phycology, 14, 387-395.

Atwater, B. F., 1987. Evidence for great earthquakes along the outer coast of Washington state. Science, 236, 942-944. doi:10.1126/science. 236.4804.942.

Atwater, B. F., Hemphill-Haley, E., 1997. Recurrence intervals for great earthquakes of the past 3,500 years at northeastern Willapa Bay, Washington. U.S. Geological Survey Professional Paper, 1576, 1-108.

Atwater, B. F., Nunez, H. J., Vita-Finzi, C., 1992. Net late Holocene emergence despite earthquake-induced submergence, south-central Chile, in: Impacts of Tectonics on Quaternary Coastal Evolution, Y. Ota, A. R. Nelson and K. R. Berryman (Editors), Quaternary International, 15/16,77-85.

Atwater, B.F., 1992. Geologic evidence for earthquakes during the past 2000 years along the Copalis River, southern coastal Washington. Journal of Geophysical Research, 97, 19011919.

Atwater, B.F., Furukawa, R., Hemphill-Haley, E., Ikeda, Y., Kashima, K., Kawase, K., Kelsey, H.M., Moore , A.L., Nanayama, F., Nishimura, Y., Odagiri, S., Ota, Y., Park, S., Satake, K., 

Holocene, 14, 489-501.

Barker, P., Fontes, J., Gasse, F., Druart, J., 1994. Experimental dissolution of diatom silica in concentrated salt solutions and implications for paleoenvironmental reconstruction. Limnology and Oceanography, 39, 99-110.

Barlow, N.L.M., Shennan, I., Long, A.J., 2012. Relative sea-level response to Little Ice Age mass change in south central Alaska: reconciling model predictions and geological evidence. Earth and Planetary Science Letters 315-316, 62-75.

Bartsch-Winkler, S., Schmoll, H.R., 1987. Earthquake-caused sedimentary couplets in the upper Cook Inlet region. U.S. Geological Survey, Circular 998, 92-95.

Battarbee, R. W., Jones, V. J., Flower, R. J., Cameron, N. G., Bennion, H., Carvalho, L., Juggins, S., 2001. Diatoms (pp. 155-202). Springer Netherlands.

Benson, B.E., Grimm, K.A., Clague, J.J., 1997. Tsunami deposits beneath tidal marshes on northwestern Vancouver Island, British Colombia. Quaternary Research, 48, 192-204.

Berkeley, A., Perry, C. T., Smithers, S. G., 2009. Taphonomic signatures and patterns of test degradation on tropical, intertidal benthic foraminifera. Marine Micropaleontology, 73(3), 148-163.

Birks, H.J.B., 1995. Statistical modelling of Quaternary science data. In: Maddy, D., Brew, J.S. (Eds.), Quantitative Paleoenvironmental Reconstructions. Quaternary Research Association, Cambridge 5, 161-254.

Bondevik, S., 2003. Storegga tsunami sand in peat below the Tapes beach ridge at Haroy, western Norway, and its possible relation to an early Stone Age settmement. Boreas, 32, 476-483.

Bondevik, S., Mangerud, J., Dawson, S., Dawson, A., Lohne, O., 2005. Evidence for three North Sea tsunamis at the Shetland Islands between 8000 and 1500 years ago. Quaternary Science Reviews, 24, 1757-1775.

Bourgeois, J., Reinhart, M.A., 1989. Onshore erosion and deposition by the 1960 tsunami at the Rio Lingue estuary, south-central Chile. American Geophysical Union Transactions, 70, 1331.

Bourgeois, J., Petroff, C., Yeh, H., Titov, V., Synolakis, C.E., Benson, B., Kuroiwa, J., Lander, J., Norabuena, E., 1999. Geologic setting, field survey and modeling of the Chimbote, Northern Peru, tsunami of 21 February 1996. Pure and Applied Geophysics, 154, 513-540.

Bourgeois, J., 2006. Earthquakes: a movement in four parts? Nature, 440, 430-431.

Briggs, R. W., Engelhart, S. E., Nelson, A. R., Dura, T., Kemp, A. C., Haeussler, P. J., Corbett, D.R., Angster, S.J., Bradley, L.A., 2014. Uplift and subsidence reveal a non-persistent megathrust rupture boundary (Sitkinak Island, Alaska). Geophysical Research Letters, 41, 2289-2296.

564 
Brill, D., Jankaew, K., Neubauer, N., Kelletat, D., Scheffers, A., Vött, Brückner, H., 2014. Holocene coastal evolution of southwest Thailand - implications for the site-specific preservation of palaeotsunami deposits. Zeitschrift für Geomorphologie, 58 (1).

Chagué-Goff, C., Dawson, S., Goff, J. R., Zachariasen, J., Berryman, K. R., Garnett, D. L., Mildenhall, D.C., 2002. A tsunami (ca. 6300 years BP) and other Holocene environmental changes, northern Hawke's Bay, New Zealand. Sedimentary Geology, 150, 89-102.

Chagué-Goff, C., Schneider, J. L., Goff, J. R., Dominey-Howes, D., Strotz, L., 2011. Expanding the proxy toolkit to help identify past events-lessons from the 2004 Indian Ocean Tsunami and the 2009 South Pacific Tsunami. Earth-Science Reviews, 107, 107-122.

Chagué-Goff, C., Goff, J., Wong, H. K., and Cisternas, M., 2015. Insights from geochemistry and diatoms to characterise a tsunami's deposit and maximum inundation limit. Marine Geology, 359, 22-34.

Chlieh, M., Avouac, J. P., Hjorleifsdottir, V., Song, T. R. A., Ji, C., Sieh, K., Galetzka, J., 2007. Coseismic slip and afterslip of the great Mw 9.15 Sumatra-Andaman earthquake of 2004. Bulletin of the Seismological Society of America, 97(1A), S152-S173.

Cisternas, M., Atwater, B.F., Torrejón, F., Sawai, Y., Machuca, G., Lagos, M., Eipert, A., Youlton, C., Salgado, I., Kamataki, T., Shishikura, M., Rajendran, C.P., Malik, J.K., Rizal, Y., Husni, M., 2005. Predecessors of the giant 1960 Chile earthquake. Nature 437, 404-407.

Clague, J.J., Bobrowsky, P.T., 1994. Evidence for a large earthquake and tsunami 100-400 years ago on western Vancouver Island, British Columbia. Quaternary Research, 41, 176-184.

Clague, J.J., Hutchinson, I., Mathewes, R.W., Patterson, R.T., 1999. Evidence for Late Holocene tsunamis at Catala Lake, British Columbia. Journal of Coastal Research 15, 45-60.

Clark, K. J., Hayward, B. W., Cochran, U. A., Grenfell, H. R., Hemphill-Haley, E., Mildenhall, D. C., Hemphill-Haley, M.A., Wallace, L. M., 2011. Investigating subduction earthquake geology along the southern Hikurangi margin using palaeoenvironmental histories of intertidal inlets. New Zealand Journal of Geology and Geophysics, 54(3), 255-271.

Clark, K. J., Hayward, B. W., Cochran, U. A., Wallace, L. M., Power, W. L., and Sabaa, A. T., 2015. Evidence for Past Subduction Earthquakes at a Plate Boundary with Widespread Upper Plate Faulting: Southern Hikurangi Margin, New Zealand. Bulletin of the Seismological Society of America.

Cleve, P.T., 1894. Synopsis of the naviculoid diatom I and II. Kongliga Svenska VetenskapsAkademien 26, 1-194.

Cleve, P.T., 1895. Synopsis of the naviculoid diatom I and II. Kongliga Svenska VetenskapsAkademien 27, 1-129.

Cleve-Euler, A., 1922. Om diatomacevegetationen och dess forandringar i Sabysjon, Uppland samt negra damda sjoar i Salatrakten. Sveriges Geologiska Undersokning C309, 1-76. 
614 Cochran, U.A., Berryman, K.R., Mildenhall, D.C., Hayward, B.W., Southall, K., Hollis, C.J., 615 2005. Towards a record of Holocene tsunami and storms for northern Hawke's Bay, New

Cochran, U., Berryman, K., Zachariasen, J., Mildenhall, D., Hayward, B., Southall, K., Hollis, K., Wilson, K., 2006. Paleoecological insights into subduction zone earthquake occurrence, eastern North Island, New Zealand. Geological Society of America Bulletin, 118, 1051-1074.

Cooper, S., Gaiser, E.E., Wachnicka, A., 2010. Estuarine paleoecological reconstructions using diatoms. In: Smol, J.P., Stoermer, E.F. (Eds.), The Diatoms: Applications for the Environmental and Earth Sciences. Cambridge University Press, Cambridge, 324-345.

Combellick, R.A., 1991. Paleoseismicity of the Cook Inlet region, Alaska: Evidence from peat stratigraphy in Turnagain and Knik Arms. Alaska Division of Geological and Geophysical Surveys Professional Report, Fairbanks, 52 pp.

Combellick, R.A., 1994. Investigation of peat stratigraphy in tidal marshes along Cook Inlet, Alaska, to determine the frequency of 1964-style great earthquakes in the Anchorage region. Alaska Division of Geological and Geophysical Surveys Report of Investigations, 94-97, Fairbanks, 24 pp.

Combellick, R., Reger, R.D., 1989. Evaluation of Holocene subsidence events of Cook Inlet estuarine flats near Anchorage, Alaska, as a basis for assessing seismic hazards in southcentral Alaska. USGS Open-File Report 89-453, 445-446.

Combellick, R.A., Reger, R.D., 1994. Sedimentological and radiocarbon- age data for tidal marshes along eastern and upper Cook Inlet, Alaska. Alaska Division of Geological and Geophysical Surveys Report of Investigations, 94-96, Fairbanks, 60 pp.

Clark, K.J., Hayward, B.W., Cochran, U.A., Wallace, L.M., Power, W.L., Sabaa, A.T., 2015. Evidence for past subduction earthquakes at a plate boundary with widespread upper plate faulting: southern Hikurangi margin, New Zealand. Bulletin of the Seismological Society of America, 105(3): doi: 10.1785/0120140291

Darienzo, M.E., Peterson, C.D., 1990. Episodic tectonic subsidence of late Holocene salt marshes, northern Oregon central Cascadia margin. Tectonics, 9, 1-22.

Darienzo, M.E., Peterson, C.D., Clough, C., 1994. Stratigraphic evidence for great subductionzone earthquakes at four estuaries in northern Oregon, USA. Journal of Coastal Research, 10, 850-876.

Dawson, S., 2007. Diatom biostratigraphy of tsunami deposits: examples from the 1998 Papua New Guinea tsunami. Sedimentary Geology, 200, 328-335.

Dawson, S., Smith, D.E., 2000. The sedimentology of mid-Holocene tsunami facies in northern Scotland. Marine Geology, 170, 69-79.

Dawson, A.G., Stewart, I., 2007. Tsunami deposits in the geological record. Sedimentary Geology, 200, 166-183. 
664

665

666

667

668

669

670

671

672

673

674

675

676

677

678

679

680

681

682

683

684

685

686

687

688

689

690

691

692

693

694

695

696

697

698

699

700

701

702

703

704

705

706

707

708

709

710

711

712

713
Dawson, S., Smith, D.E., Ruffman, A., Shi, S., 1996a. The diatom biostratigraphy of tsunami deposits: Examples from recent and middle Holocene events. Physics and Chemistry of the Earth, 21, 87-92.

Dawson, A.G., Shi, S., Dawson, S., Takahashi, T., Shuto, N., 1996b. Coastal sedimentation associated with the June 2nd and 3rd, 1994 tsunami in Rajegwesi, Java. Quaternary Science Reviews, 15, 901-912.

Denys, L., 1991-1992. A check-list of the diatoms in the Holocene deposits of the western Belgian coastal plain with a survey of their apparent ecological requirements. Ministère des affaires économiques, Service Géologique de Belgique.

Dominey-Howes, D., Cundy, A., Croudace, I., 2000. High energy marine flood deposits on Astypalaea Island, Greece: possible evidence for the AD 1956 southern Aegean tsunami. Marine Geology, 163, 303-315.

Dura, T., Rubin, C.M., Kelsey, H.M., Horton, B.P., Hawkes, A.D., Vane, C.H., Daryono, M., Grand Pre, C., Ladinsky, T., Bradley, S., 2011. Stratigraphic record of Holocene coseismic subsidence, Padang, West Sumatra. Journal of Geophysical Research, 116, B11306.

Dura, T., Cisternas, M., Horton, B.P., Ely, L.L., Nelson, A.R., Wesson, R.L., Pilarczyk, J.E., 2015. Coastal evidence for Holocene subduction-zone earthquakes and tsunamis in central Chile. Quaternary Science Reviews, 113, 93-111.

Ely, L.L., Cisternas, M., Wesson, R.L., Dura, T., 2014. Five centuries of tsunamis and land-level changes in the overlapping rupture area of the 1960 and 2010 Chilean earthquakes. Geology. G35830-1.

Engelhart, S.E., Horton, B.P., Nelson, A.R., Hawkes, A.D., Witter, R.C., Wang, K., Wang, P-.L., Vane, C.H., 2013. Testing the use of microfossils to reconstruct great earthquakes at Cascadia. Geology, 41(10), 1067-1070. doi, 10.1130/G34544.1

Engelhart, S. E., Horton, B. P., Vane, C. H., Nelson, A. R., Witter, R. C., Brody, S. R., Hawkes, A. D., 2013. Modern foraminifera, $\delta^{13} \mathrm{C}$, and bulk geochemistry of central Oregon tidal marshes and their application in paleoseismology. Palaeogeography, Palaeoclimatology, Palaeoecology, 377, 13-27.

Flower, R. J., 1993. Diatom preservation: experiments and observations on dissolution and breakage in modern and fossil material. Hydrobiologia, 269/270, 473-84.

Garrett, E., Shennan, I., Watcham, E.P., Woodroffe, S.A., 2013. Reconstructing paleoseismic deformation, 1: modern analogues from the 1960 and 2010 Chilean great earthquakes. Quaternary Science Reviews, 75, 11-21.

Garrett, E., Shennan, I., Woodroffe, S. A., Cisternas, M., Hocking, E. P., Gulliver, P., 2015. Reconstructing paleoseismic deformation, 2: 1000 years of great earthquakes at Chucalén, south central Chile. Quaternary Science Reviews, 113, 112-122.

Geller, R. J., 2011. Shake-up time for Japanese seismology. Nature, 472, 407-409. 
714

715

716

717

718

719

720

721

722

723

724

725

726

727

728

729

730

731

732

733

734

735

736

737

738

739

740

741

742

743

744

745

746

747

748

749

750

751

752

753

754

755

756

757

758

759

760

761

Gelfenbaum, G., Jaffe, B., 2003. Erosion and sedimentation from the 17 July 1998 Papua New Guinea tsunami. Pure and Applied Geophysics, 160, 1969-1999.

Goff, J., McFadgen, B. G., Chagué-Goff, C., 2004. Sedimentary differences between the 2002 Easter storm and the 15th-century Okoropunga tsunami, southeastern North Island, New Zealand. Marine geology, 204(1), 235-250.

Goff, J., Liu, P. L., Higman, B., Morton, R., Jaffe, B. E., Fernando, H., Fernando, S., 2006. Sri Lanka field survey after the December 2004 Indian Ocean tsunami. Earthquake Spectra, 22, 155-172.

Goff, J., Lamarche, G., Pelletier, B., Chagué-Goff, C., Strotz, L., 2011. Predecessors to the 2009 South Pacific tsunami in the Wallis and Futuna archipelago. Earth-Science Reviews 107, 91106.

Goff, J., Chagué-Goff, Nichol, S., Jaffe, B., Dominey-Howes, D., 2012. Progress in palaeotsunami research. Sedimentary Geology, 243, 70-88.

Goto, T., Satake, K., Sugai, T., Ishibe, T., Harada, T., Murotani, S., 2015. Historical tsunami and storm deposits during the last five centuries on the Sanriku coast, Japan. Marine Geology.

Graehl, N. A., Kelsey, H. M., Witter, R. C., Hemphill-Haley, E., and Engelhart, S. E., 2015. Stratigraphic and microfossil evidence for a 4500-year history of Cascadia subduction zone earthquakes and tsunamis at Yaquina River estuary, Oregon, USA. Geological Society of America Bulletin, 127(1-2), 211-226.

Grand Pre, C.A., Horton, B.P., Kelsey, H.M., Rubin, C.M., Hawkes, A.D., Daryono, M.R., Rosenberg, G., Culver, S.J., 2012. Stratigraphic evidence for an early Holocene earthquake in Aceh, Indonesia. Quaternary Science Reviews, 54, 142-151.

Grauert, M., Björck, S., Bondevik, S., 2001, Storegga tsunami deposits in a coastal lake on Suduroy, the Faroe Islands: Boreas, 30, 263-271.

Guilbault, J.P., Clague, J.J., Lapointe, M., 1995. Amount of subsidence during a late Holocene earthquake - Evidence from fossil tidal marsh foraminifera at Vancouver Island, west coast of Canada. Palaeogeography Palaeoclimatology Palaeoecology, 118, 49-71.

Guilbault, J.-P., Clague, J.J., Lapointe, M., 1996. Foraminiferal evidene for the amount of coseismic subsidence during a late Holocene earhquake on Vancouver Island, west coast of Canada. Quaternary Science Reviews, 15, 913-937.

Hamilton, S., Shennan, I., 2005a. Late Holocene relative sea-level changes and the earthquake deformation cycle around upper Cook Inlet, Alaska. Quaternary Science Reviews, 24, 14791498.

Hamilton, S., and Shennan, I., 2005b. Late Holocene great earthquakes and relative sea-level change at Kenai, southern Alaska. Journal of Quaternary Science, 20(2), 95-111. 
762

763

764

765

766

767

768

769

770

771

772

773

774

775

776

777

778

779

780

781

782

783

784

785

786

787

788

789

790

791

792

793

794

795

796

797

798

799

800

801

802

803

804

805

806

807

808

809

810

811

812

Hamilton S, Shennan I, Combellick R, Mulholland, J., Noble, C., 2005. Evidence for two great earthquakes at Anchorage, Alaska and implications for multiple great earthquakes through the Holocene. Quaternary Science Reviews 24: 2050-2068.

Hartley, B., Ross, R., Williams, D.M., 1996. A check-list of the freshwater, brackish and marine diatoms of the British Isles and adjoining coastal waters. Journal of the Marine Biological Association of the United Kingdom 66, no. 03: 531-610.

Hawkes, A. D., Bird, M., Cowie, S., Grundy-Warr, C., Horton, B. P., Hwai, A. T. S., Law, L., Macgregor, C., Nott, J., Eong Ong, J., Rigg, J., Robinson, R., Tan-Mullins, M., Tiong Sa, T., Yasin, Z., Aik, L. W., 2007. Sediments deposited by the 2004 Indian Ocean tsunami along the Malaysia-Thailand Peninsula. Marine Geology, 242(1), 169-190.

Hawkes, A. D., Horton, B. P., Nelson, A. R., Hill, D. F., 2010. The application of intertidal foraminifera to reconstruct coastal subsidence during the giant Cascadia earthquake of $\mathrm{AD}$ 1700 in Oregon, USA. Quaternary International,221(1), 116-140.

Hawkes, A.D., Horton, B.P., Nelson, A.R., Vane, C.H., Sawai, Y., 2011. Coastal subsidence in Oregon, USA, during the giant Cascadia earthquake of AD 1700. Quaternary Science Reviews, 30, 364-376.

Hayward, B. W., Grenfell, H. R., Sabaa, A. T., Carter, R., Cochran, U., Lipps, J. H., Shane, P.R., Morley, M. S., 2006. Micropaleontological evidence of large earthquakes in the past 7200 years in southern Hawke's Bay, New Zealand. Quaternary Science Reviews, 25(11), 11861207.

Heki, K., 2011. A tale of two earthquakes. Science, 332, 1390-1391.

Hemphill-Haley, E., 1993. Taxonomy of recent and fossil (Holocene) diatoms (Bacillariophyta) from northern Willapa Bay, Washington (No. 93-289). US Geological Survey,.

Hemphill-Haley, E., 1995a. Diatom evidence for earthquake-induced subsidence and tsunami 300 years ago in southern coastal Washington. Geological Society of America Bulletin, 107, 367378.

Hemphill-Haley, E., 1995b. Intertidal diatoms from Willapa Bay, Washington: applications to studies of small-scale sea-level changes. Northwest Science, 69, 29-45.

Hemphill-Haley, E., 1996. Diatoms as an aid in identifying late Holocene tsunami deposits. The Holocene, 6, 439-448.

Horton, B.P., 1999. The distribution of contemporary intertidal foraminifera at Cowpen Marsh, Tees Estuary, UK: implications for studies of Holocene sea-level changes. Palaeogeography, Palaeoclimatology, Palaeoecology, 149, 127-149.

Horton, B.P., Edwards, R.J., 2005. The application of local and regional transfer functions to reconstruct former sea levels, North Norfolk, England. The Holocene, 15, 216-228.

Horton, B.P., Edwards, R.J., 2006. Quantifying Holocene sea level change using intertidal foraminifera: lessons from the British Isles. Cushman Foundation for Foraminiferal Research, Special Publication 40, 97 pp. 
Horton, B. P., Zong, Y., Hillier, C., Engelhart, S., 2007. Diatoms from Indonesian mangroves and their suitability as sea-level indicators for tropical environments. Marine Micropaleontology, 63, 155-168.

Horton, B.P., Rossi, V., Hawkes, A.D., 2009. The sedimentary record of the 2005 hurricane season from the Mississippi and Alabama coastlines. Quaternary International, 195, 15-30.

Horton, B. P., Sawai, Y., Smol, J. P., Stoermer, E. F., 2010. Diatoms as indicators of former sea levels, earthquakes, tsunamis, and hurricanes. The diatoms: applications for the environmental and earth sciences, (Ed. 2), 357-372.

Horton, B.P., Sawai, Y., Hawkes, A.D., Witter, R.C., 2011. Sedimentology and paleontology of a tsunami deposit accompanying the great Chilean earthquake of February 2010. Marine Micropaleontology, 79, 132-138.

Horton, B.P., Engelhart, S.E., Kemp, A.C., Sawai, Y., 2013. Microfossils in tidal settings as indicators of sea-level change, paleoearthquakes, tsunamis, and tropical cyclones. In: John F. Shroder (ed.) Treatise on Geomorphology, vol. 14, San Diego: Academic Press, 292-314.

Hughes, J.F., Mathewes, R.W., Clague, J.J., 2002. Use of pollen and vascular plants to estimate coseismic subsidence at a tidal marsh near Tofino, British Columbia. Palaeogeography Palaeoclimatology Palaeoecology, 185, 145-161.

Hustedt, F., 1937. Systematische und okologische Untersuchungen der Diatomeen floren von Java, Bali, Sumatra. Archiv Hydrobiologie Supplement, 15, 131-506.

Hustedt, F., 1939. Systematische und okologische Untersuchungen der Diatomeen floren von Java, Bali, Sumatra. Archiv Hydrobiologie Supplement, 16, 1-394.

Hustedt, F., 1953. Diatomeen ausdem Naturschutzpark Seeon. Archiv f ur Hydrobiologie, 47, $625-35$.

Hustedt, F., 1957. Die Diatomeenflora des Fluss-systems der Weser im Gebiet der Hansestadt Bremen. Abhandlungen vom Naturwissenschaftlichen Verein zu Bremen 34, 181-440.

Hustedt, F., 1958. Diatomeen aus der Antarktis and dem Siidatlantik. Deutsche Antarkt. Exped. 1938/39, Wiss. Ergebn., 2 103-191.

Hutchinson, I., Clague, J.J., Mathewes, R.W., 1997. Reconstructing the tsumani record on an emerging coast: A case study of Kanim Lake, Vancouver Island, British Columbia, Canada: Journal of Coastal Research, 13, 545-553.

Hutchinson, I., Guilbault, J. P., Clague, J. J., Bobrowsky, P. T., 2000. Tsunamis and tectonic deformation at the northern Cascadia margin: a 3000-year record from Deserted Lake, Vancouver Island, British Columbia, Canada. The Holocene, 10(4), 429-439.

Iliev, A. Y., Kaistrenko, V. M., Gretskaya, E. V., Tikhonchuk, E. A., Razjigaeva, N. G., Grebennikova, T. A., and Kharlamov, A. A., 2005. Holocene tsunami traces on Kunashir Island, Kurile subduction zone. In Tsunamis (pp. 171-192). Springer Netherlands. 
864

865

866

867

868

869

870

871

872

873

874

875

876

877

878

879

880

881

882

883

884

885

886

887

888

889

890

891

892

893

894

895

896

897

898

899

900

901

902

903

904

905

906

907

908

909

910

911

912

913

914

James, T., Gowan, E. J., Hutchinson, I., Clague, J. J., Barrie, J. V., Conway, K. W., 2009. Sealevel change and paleogeographic reconstructions, southern Vancouver Island, British Columbia, Canada. Quaternary Science Reviews, 28(13), 1200-1216.

Jankaew, K., Atwater, B.F., Sawai, Y., Choowong, M., Charoentitirat, T., Martin, M.E., Prendergast, A., 2008. Medieval forewarning of the 2004 Indian Ocean tsunami in Thailand. Nature, 455, 1228-1231.

Jones, V.J., 2007. Diatom Introduction, in: Elias, S., (Ed.) Encyclopedia of Quaternary Science. Elsevier, Oxford, pp. 476 - 484.

Juggins, S., 1992. Diatoms in the Thames estuary, England: ecology, palaeoecology, and salinity transfer function. Bibliotheca Diatomologica, 25, 216.

Kamatani, A., 1982. Dissolution rates of silica from diatoms decomposing at various temperatures. Marine Biology, 68, 91-96.

Kelsey, H. M., Witter, R. C., Hemphill-Haley, E., 2002. Plate-boundary earthquakes and tsunamis of the past $5500 \mathrm{yr}$, Sixes River estuary, southern Oregon. Geological Society of America Bulletin, 114(3), 298-314.

Kelsey, H. M., Sherrod, B., Johnson, S. Y., Dadisman, S. V., 2004. Land-level changes from a late Holocene earthquake in the northern Puget Lowland, Washington. Geology, 32(6), 469472.

Kelsey, H.M., Nelson, A.R., Hemphill-Haley, E., Witter, R.C., 2005. Tsunami history of an Oregon coastal lake reveals a $4600 \mathrm{yr}$ record of great earthquakes on the Cascadia subduction zone. Geological Society of America Bulletin, 117, 1009-1032.

Kemp, A.C., Horton, B.P., Culver, S.J., Corbett, D.R., van de Plassche, O., Gehrels, W.R., Douglas, B.C., Parnell, A.C., 2009. Timing and magnitude of recent accelerated sea-level rise (North Carolina, United States). Geology, 37, 1035-1038.

Kokociński, M., Szczuciński, W., Zgrundo, A., and Ibragimow, A., 2009. Diatom assemblages in 26 December 2004 tsunami deposits from coastal zone of Thailand as sediment provenance indicators. Polish Journal of Environmental Studies, 18(1), 93-101.

Kon'no, E., 1961. Geological observations of the Sanriku coastal region damaged by tsunami due to the Chile earthquake in 1960, Contributions to the Institute of Geology and Paleontology of Tohoku University, 52, 1-40. (in Japanese with English abstract)

Kortekaas, S., Dawson, A. G., 2007. Distinguishing tsunami and storm deposits: an example from Martinhal, SW Portugal. Sedimentary Geology, 200, 208-221.

Krammer, K., Lange-Bertalot, H., 1986. Bacillarophyceae 2/1. Naviculaceae, in: Ettl, H., Gerloff, J., Heynig, H., Mollenhauser (Eds.), Su $\square$ sswasserflora von Mitteleuropa. Gustav Fischer Verlag, Stuttgart, pp. 1-876.

Krammer, K., Lange-Bertalot, H., 1988. Bacillarophyceae 2/2. Basillariaceae, Epithemiaceae, Surirellaceae, in: Ettl, H., Gerloff, J., Heynig, H., Mollenhauser (Eds.), Su $\square$ sswasserflora von Mitteleuropa. Gustav Fischer Verlag, Stuttgart, pp. 1-600. 
Krammer, K., Lange-Bertalot, H., 1991a. Bacillarophyceae 2/3. Centrales, Fragilariaceae, Eunotiaceae, in: Ettl, H., Gerloff, J., Heynig, H., Mollenhauser (Eds.), Su $\square$ sswasserflora von Mitteleuropa. Gustav Fischer Verlag, Stuttgart, pp. 1-600.

Krammer, K., Lange-Bertalot, H., 1991b. Bacillarophyceae 2/4. Achnanthaceae, Kritische Erganzungen zu Navicula (Lineolatae) und Gomphonema, in: Ettl, H. (Ed.), Pascher's $\mathrm{Su} \square$ sswasserflora von Mitteleuropa, vol. 2, part 4. Gustav Fischer Verlag, Stuttgart, pp. 1437.

Krammer, K., 2000. Diatoms of Europe: Diatoms of European Inland Water and Comparable Habitats, Vol. 1: The genus Pinnularia. Edited by Horst Lange-Bertalot, Ruggell : Gantner,

Krammer, K., 2002. Diatoms of Europe: Diatoms of European Inland Water and Comparable Habitats, Vol. 3: The genus Cymbella. Edited by Horst Lange-Bertalot, Ruggell : Gantner,

Krammer, K., 2003. Diatoms of Europe: Diatoms of European Inland Water and Comparable Habitats, Vol. 4: Cymbopleura, Delicata, Navicymbula, Gomphocymbellopsis, Afrocymbell.. Edited by Horst Lange-Bertalot, Ruggell : Gantner,

Lajoie, K. R., 1986. Coastal tectonics. Active tectonics, 95-124.

Lange-Bertalot, H., 2000. Iconographia Diatomologica Annotated Diatom Micrographs - Diatom Flora of Marine Coasts I, Edited: H. Lange-Bertalot; Vol. 7 Pub: Koeltz Scientific Books. Copyright: A.R.G. Gantner Verlag K.G. By: Andrzej Witkowiski, Horst Lange- Bertalot and Ditmar Metzeltin.

Lange-Bertalot, H., 2001. Diatoms of Europe: Diatoms of European Inland Water and Comparable Habitats, Vol. 2: Navicula sensu stricto, 10 Genera Separated from Navicula sensu stricto, Frustulia. Edited by Horst Lange-Bertalot, Ruggell : Gantner.

Lange-Bertalot, H., Bak, M., Witkowski, A., Tagliaventi, N., 2011. Diatoms of Europe: Diatoms of European Inland Water and Comparable Habitats, Vol. 6: Eunotia and some related genera. Edited by Horst Lange-Bertalot, Ruggell : Gantner.

Leonard, L.J., Currie, C.A., Mazzotti, S., Hyndman, R.D., 2010. Rupture area and displacement of past Cascadia great earthquakes from coastal coseismic subsidence. Geological Society of America Bulletin, 112, 2079-2096.

Levkov, Z., 2009. Diatoms of Europe: Diatoms of European Inland Water and Comparable Habitats, Vol. 5: Amphora sensu lato. Edited by Horst Lange-Bertalot, Ruggell : Gantner.

Liu, K.-b, Fearn, M.L., 2000. Reconstruction of prehistoric landfall frequencies of catastrophic hurricanes in northwestern Florida from lake sediment records. Quat. Res. 54, 238-245.

Lowe, R. L., 1974. Environmental Requirements and Pollution Tolerance of Freshwater Diatoms. EPA-670/4-74-005. Cincinnati, OH. 344 pp.

Malik, J. N., Shishikura, M., Echigo, T., Ikeda, Y., Satake, K., Kayanne, H., Dikshit, O., 2011. Geologic evidence for two pre-2004 earthquakes during recent centuries near Port Blair, South Andaman Island, India. Geology, 39(6), 559-562. 

assemblages. Earth-Science Reviews, 96, 263-278.

Minoura, K., and Nakaya, S., 1991. Traces of tsunami preserved in inter-tidal lacustrine and marsh deposits - some examples from northeast Japan. Journal of Geology, 99, 265-287.

Minoura, K., Nakaya, S., and Uchida, M., 1994. Tsunami deposits in a lacustrine sequence of the Sanriku coast, northeast Japan. Sedimentary Geology, 89(1), 25-31.

Minoura, K., Imamura, F., Sugawara, D., Kono, Y., 2001. The 869 Jogan tsunami deposit and recurrence interval of large-scale tsunami on the Pacific coast of northeast Japan. Journal of Natural Disaster Science, 23, 83-88.

Monecke, K., Finger, W., Klarer, D., Kongko, W., McAdoo, B.G., Moore, A.L., Sudrajat, S.U., 2008. A 1,000-year sediment record of tsunami recurrence in northern Sumatra. Nature, 455, 1232-1234.

Morton, R. A., Gelfenbaum, G., Jaffe, B. E., 2007. Physical criteria for distinguishing sandy tsunami and storm deposits using modern examples. Sedimentary Geology, 200(3), 184-207.

Murray, J. W., 1991. Ecology and palaeoecology of benthic foraminifera. Longman Scientific and Technical, Harlow, England. 397 pp.

Nanayama, F., Shigeno, K., Satake, K., Shimokawa, K., Koitabashi, S., Miyasaka, S., Ishii, M., 2000. Sedimentary differences between the 1993 Hokkaido-nansei-oki tsunami and the 1959 Miyakojima typhoon at Taisei, southwestern Hokkaido, northern Japan. Sedimentary Geology, 135(1), 255-264.

Nanayama, F., Satake, K., Furukawa, R., Shimokawa, K., Atwater, B.F., Shigeno, K., Yamaki, S., 2003. Unusually large earthquakes inferred from tsunami deposits along the Kuril Trench. Nature, 424, 660-663.

Nanayama, F., Furukawa, R., Shigeno, K., Makino, A., Soeda, Y., Igarashi, Y., 2007. Nine unusually large tsunami deposits from the past 4000 years at Kiritappu marsh along the southern Kuril Trench. Sedimentary Geology, 200, 275-294.

Nelson, A. R., 1992. Discordant $14 \mathrm{C}$ ages from buried tidal-marsh soils in the Cascadia subduction zone, southern Oregon coast. Quaternary Research,38(1), 74-90.

Nelson, A.R., Kashima, K., 1993. Diatom zonation in southern Oregon tidal marshes relative to vascular plants, foraminifera, and sea level. Journal of Coastal Research, 9, 673-697.

Nelson, A.R., Atwater, B.F., Bobrowsky, P.T., Bradley, L.A., Clague, J.J., Carver, G.A., Darienzo, M.E., Grant, W.C., Krueger, H.W., Sparks, R., Stafford, T.W., Stuiver, M., 1995. Radiocarbon evidence for extensive plate-boundary rupture about 300 years ago at the Cascadia subduction zone. Nature 378, 371-374.

Nelson, A.R., Jennings, A.E., Kashima, K., 1996a. Holocene intertidal stratigraphy, microfossils, rapid submergence, and earthquake recurrence at Coos Bay, southern coastal Oregon, USA. Geological Society of America Bulletin, 108, 141-154.

1017 
1018

1019

1020

1021

1022

1023

1024

1025

1026

1027

1028

1029

1030

1031

1032

1033

1034

1035

1036

1037

1038

1039

1040

1041

1042

1043

1044

1045

1046

1047

1048

1049

1050

1051

1052

1053

1054

1055

1056

1057

1058

1059

1060

1061

1062

1063

1064

1065

1066

1067

1068

Nelson, A.R., Shennan, E., Long, A.J., 1996b. Identifying coseismic subsidence in tidal-wetland stratigraphic sequences at the Cascadia subduction zone of western North America. Journal of Geophysical Research 101, 6115-6135.

Nelson, A. R., Sawai, Y., Jennings, A. E., Bradley, L. A., Gerson, L., Sherrod, B. L., Sabean, J., Horton, B. P., 2008. Great-earthquake paleogeodesy and tsunamis of the past 2000 years at Alsea Bay, central Oregon coast, USA. Quaternary Science Reviews, 27(7), 747-768.

Nelson, A.R., Kashima, K., Bradley, L., 2009. Fragmentary evidence of great - earthquake subsidence during Holocene emergence, Valdivia Estuary, South Central Chile. Bulletin of the Seismological Society of America, 99. 71-86.

Nelson, A. R., 2013. Paleoseismology. Encyclopedia of Natural Hazards, 749-750.

Nelson, A.R., 2015. Coastal Sediments. in Handbook of Sea-level Research. Shennan, I., Long, A. J., Horton, B. P. (Eds.). John Wiley and Sons.

Nelson, A. R., Briggs, R. W., Dura, T., Engelhart, S. E., Gelfenbaum, G., Bradley, L. A., Formans, S.L., Vane, C.V., Kelley, K. A., 2015. Tsunami recurrence in the eastern AlaskaAleutian arc: A Holocene stratigraphic record from Chirikof Island, Alaska. Geosphere, 11(4), 1172-1203.

Nichol, S. L., Goff, J. R., Devoy, R. J. N., Chagué-Goff, C., Hayward, B., James, I., 2007. Lagoon subsidence and tsunami on the West Coast of New Zealand. Sedimentary Geology, 200, 248-262.

Palmer, A.J.M., Abbott, W.H., 1986. Diatoms as indicators of sea-level change. In: can de Plassche, O. (Ed.), Sea-level Research: A Manual for the Collection and Evaluation of Data. Geobooks, Norwich, pp. 457-488.

Pararas-Carayannis, G., 2003. Near and far-field effects of tsunamis generated by the PAroxysmal eruptions, explosions, Caldera collapses and massive slope failures of the Krakatau volcano in Indonesia on August 26-27, 1883. Science of Tsunami Hazards.

Parsons, M.L., 1998. Salt marsh sedimentary record of the landfall of Hurricane Andrew on the Louisiana coast: diatoms and other paleoindicators. Journal of Coastal Research 14, 939-950.

Patrick, R. M., Reimer, C.W., 1966. The diatoms of the United States exclusive of Alaska and Hawaii, Volume 1: Monographs of the Academy of Natural Sciences of Philadelphia, 688.

Patrick, R. M., Reimer, C.W., 1975, The diatoms of the United States exclusive of Alaska and Hawaii, Volume 2: Monographs of the Academy of Natural Sciences of Philadelphia, 213.

Patrick, R., Williams, D.D., 1990. Aquatic biota in North America. In: Wolman, M.G., Riggs, H.D., (eds.), Surface water hydrology: Boulder, Colorado, Geological Society of America, the Geology of North America, v 0-1.

Patterson, R.T., Dalby, A.P., Roe, H.M., Guilbault, J.-P., Hutchinson, I., Clague, J.J., 2005. Relative utility of foraminifera, diatoms and macrophytes as high resolution indicators of paleo-sea level in coastal British Columbia, Canada. Quaternary Science Reviews 24, 20022014. 
Peterson, C.D., Carver, G.A., Cruikshank, K.M., Abramson, H.F., Garrison-Laney, C.E., 

Planets Space, 59, 381-390.

Satake, K., Atwater, B.F., 2007. Long-term perspectives on giant earthquakes and tsunamis at subduction zones. Annual Review of Earth and Planetary Sciences, 35, 349-374.

Savage, J. C., L. M. Hastie, 1966. Surface deformation associated with dip-slip faulting, J. Geophys. Res., 71(20), 4897-4904.

Sawai, Y., 2001a. Episodic emergence in the past 3000 years at the Akkeshi Estuary, Hokkaido, Northern Japan. Quaternary Research, 56, 231-241.

Sawai Y., 2001b. Distribution of living and dead diatoms in tidal wetlands of northern Japan: relations to taphonomy. Palaeogeography Palaeoclimatology Palaeoecology, 173, 125-141.

Sawai, Y., Nasu, H., Yasuda, Y., 2002. Fluctuations in relative sea-level during the past $3000 \mathrm{yr}$ in the Onnetoh estuary, Hokkaido, northern Japan. Journal of Quaternary Science, 17, 607622.

Sawai, Y., Satake, K., Takanobu, K., Nasu, H., Shishikura, M., Atwater, B.F., Horton, B.P., Kelsey, H.M., Nagumo, T., Yamaguchi, M., 2004a. Transient uplift after a $17^{\text {th }}$-century earthquake along the Kuril subduction zone. Science 306, 1918-1920.

Sawai, Y., Horton, B.P., Nagumo, T., 2004b. The development of a diatom-based transfer function along the Pacific coast of eastern Hokkaido, northern Japan - an aid in paleoseismic studies of the Kuril subduction zone. Quaternary Science Reviews 23, 2467-2483.

Sawai, Y., Fujii, Y., Fujiwara, O., Kamataki, T., Komatsubara, J., Okamura, Y., Satake, K., Shishikura, M., 2008. Marine incursions of the past 1500 years and evidence of tsunamis at the Suijin-numa, a coastal lake facing the Japan Trench. The Holocene, 18, 517-528.

Sawai, Y., Jankaew, K., Martin, M.E., Prendergast, A., Choowong, M., Charoentitirat, T., 2009a. Diatom assemblages in tsunami deposits associated with the 2004 Indian Ocean tsunami at Phra Thong Island, Thailand. Marine Micropaleontology, 73, 70-79.

Sawai, Y., Kamataki, T., Shishikura, M., Nasu, H., Okamura, Y., Satake, K., Thomson, K.H., Matsumoto, D., Fujii, Y., Komatsubara, J., Aung, T.T., 2009b. Aperiodic recurrence of geologically recorded tsunamis during the past 5500 years in eastern Hokkaido, Japan . Journal of Geophysical Research, 114, B01319, doi:10.1029/2007JB005503

Sawai, Y., Namegaya, Y., Okamura, Y., Satake, K., Shishikura, M., 2012. Challenges of anticipating the 2011 Tohoku earthquake and tsunami using coastal geology. Geophysical Research Letters, 39, L21309, doi: 10.1029/2012GL053692

Sawai, Y., Namegaya, Y., Tamura, T., Nakashima, R., Tanigawa, K., 2015. Shorter intervals between great earthquakes near Sendai: Scour ponds and a sand layer attributable to AD 1454

1167 
Shennan, I., Long, A.J., Rutherford, M.M., Green, F.M., Innes, J.B., Lloyd, J.M., Zong, Y., Walker, K.J., 1996. Tidal marsh stratigraphy, sea level change and large earthquakes: I. A 5000 year record in Washington. Quaternary Science Reviews, 15, 1023-1059.

Shennan, I., Long, A.J., Rutherford, M.M., Innes, J.B., Green, F.M., Walker, K.J., 1998. Tidal marsh stratigraphy, sea-level change and large earthquakes: II. Submergence events during the last 3500 years at Netarts Bay, Oregon. Quaternary Science Reviews 17, 365-393.

Shennan, I., Scott, D.B., Rutherford, M.M., Zong, Y., 1999. Microfossil analysis of sediments representing the 1964 earthquake, exposed at Girdwood Flats, Alaska. Quaternary International, 60, 55-73.

Shennan, I., Hamilton, S., 2006. Coseismic and preseismic subsidence associated with great earthquakes in Alaska. Quaternary Science Reviews 25, 1-8.

Shennan, I., Bruhn, R., Plafker, G., 2009. Multi-segment earthquakes and tsunami potential of the Aleutian megathrust. Quaternary Science Reviews, 28, 7-13.

Shennan, I., Bruhn, R., Barlow, N., Good, K., Hocking, E., 2014a. Late Holocene great earthquakes in the eastern part of the Aleutian megathrust. Quaternary Science Reviews, 84, 86-97.

Shennan, I., Barlow, N., Carver, G., Davies, F., Garrett, E., Hocking, E., 2014b. Great tsunamigenic earthquakes during the past $1000 \mathrm{yr}$ on the Alaska megathrust. Geology, 42, 687-690.

Sherrod, B.L., 1999. Gradient analysis of diatom assemblages in a Puget Sound salt marsh: can such assemblages be used for quantitative paleoecological reconstructions? Palaeogeography, Palaeoclimatology, Palaeoecology, 149, 213-226.

Sherrod, B. L., 2001. Evidence for earthquake-induced subsidence about $1100 \mathrm{yr}$ ago in coastal marshes of southern Puget Sound, Washington. Geological Society of America Bulletin, 113(10), 1299-1311.

Sherrod, B. L., Bucknam, R. C., Leopold, E. B., 2000. Holocene relative sea level changes along the Seattle Fault at Restoration Point, Washington. Quaternary Research, 54(3), 384-393.

Shimazaki, K., Kim, H. Y., Chiba, T., Satake, K., 2011. Geological evidence of recurrent great Kanto earthquakes at the Miura Peninsula, Japan. Journal of Geophysical Research: Solid Earth (1978-2012), 116(B12).

Simons, M., Minson, S.E., Sladen, A., Ortega, F., Jiang, J., Owen, S.E., Meng, L., Ampuero, J-P., Wei, S., Chu, R., Helmberger, D.V., Kanamori, H., Hetland, E., Moore, A.W., Webb, F.H. 2011. The 2011 magnitude 9.0 Tohoku-oki earthquake: mosaicking the megathrust from seconds to centuries. Science 332, 1421-1425.

Small, C., Gornitz, V., Cohen, J.E., 2000. Coastal hazards and the global distribution of human population. Environmental Geosciences, 7, 3-12. 
Smith, D.E., Shi, S., Cullingford, R.A., Dawson, A.G., Dawson, S., Firth, C.R., Foster, I.D.L.,

Stein, S., Okal, E.A., 2007. Ultralong period seismic study of the December 2004 Indian Ocean earthquake and implications for regional tectonics and the subduction process. Bulletin of the Seismological Society of America, 97, S279-S295.

Stein, S., Okal, E. A., 2011. The size of the 2011 Tohoku earthquake need not have been a surprise. Eos Transactions of the American Geophysical Union, 92, 227.

Stewart, I. S., Vita-Finzi, C. (Eds.), 1998. Coastal tectonics. Geological Society of London.

Sugawara, D., Minoura, K., Nemoto, N., Tsukawaki, S., Goto, K., Imamura, F., 2009. Foraminiferal evidence of submarine sediment transport and deposition by backwash during the 2004 Indian Ocean tsunami. Island Arc, 18(3), 513-525.

Switzer, A. D., Jones, B. G., 2008. Large-scale washover sedimentation in a freshwater lagoon from the southeast Australian coast: sea-level change, tsunami or exceptionally large storm?. The Holocene, 18(5), 787-803.

Szczuciński, W., 2012a. The post-depositional changes of the onshore 2004 tsunami deposits on the Andaman Sea coast of Thailand. Natural Hazards, 60, 115-133.

Szczuciński, W., M. Kokociński, M. Rzeszewski, C. Chagué-Goff, M. Cachão, K. Goto, Sugawara, D., 2012b. Sediment sources and sedimentation processes of 2011 Tohoku-oki tsunami deposits on the Sendai Plain, Japan - Insights from diatoms, nannoliths and grain size distribution. Sedimentary Geology, 282, 40-56.

Szkornik, K., Gehrels, W. R., Kirby, J. R., 2006. Using salt-marsh diatoms to reconstruct sealevel changes in Ho Bugt western Denmark. Marine Geology, 235, 137-50.

Takashimizu, Y., Urabe, A., Suzuki, K., Sato, Y., 2012. Deposition by the 2011 Tohoku-oki tsunami on coastal lowland controlled by beach ridges near Sendai, Japan. Sedimentary Geology, 282, 124-141.

Telford, R.J., Birks, H.J.B., 2011a. A novel method for assessing the statistical significance of quantitative reconstructions inferred from biotic assemblages. Quaternary Science Reviews, 30, 1272-1278.

Telford, R.J., Birks, H.J.B., 2011. Effect of uneven sampling along an environmental gradient on transfer-function performance. Journal of Paleolimnology, 46, 99-106.

Tuttle, M. P., Ruffman, A., Anderson, T., Jeter, H., 2004. Distinguishing tsunami from storm deposits in eastern North America: the 1929 Grand Banks tsunami versus the 1991 Halloween storm. Seismological Research Letters, 75 (1), 117-131.

Van Dam, H., Mertens, A., and Sinkeldam, J., 1994. A coded checklist and ecological indicator values of freshwater diatoms from the Netherlands. Netherland Journal of Aquatic Ecology, 28(1), 117-133. 

2006. Salt-marsh erosion associated with hurricane landfall in southern New England in the fifteenth and seventeenth centuries. Geology, 34, 829-832.

van der Werff, H., Huls, H., 1958-1974. Diatomeeenflora van Nederland, 8 parts, published privately, De Hoef, The Netherlands.

Vos, P.C., 1986. De sediment stabiliserende werking van benthische diatomeen in het intergetijde gebied van de Oosterschelde . GEOMOR-nota 86-03, Rijkswaterstaat, Dienst Getijde-wateren, Middelburg, 156 pp.

Vos, P.C., de Boer, P.L., Misdorp, R., 1988. Sediment stabilization by benthic diatoms in intertidal sandy shoals, in: P. L. de Boer, A. van Gelder and S . D . Nio (Eds), Tide influenced sedimentary environments and facies, D.Reidel Publishing Company, Dordrecht, pp. 511526.

Vos, P.C., de Wolf, H., 1988. Methodological aspects of paleo-ecological diatom research in coastal areas of the Netherlands. Geol Mijnbouw 67: 31-40.

Vos, P.C., de Wolf, H., 1993. Diatoms as a tool for reconstruction sedimentary environments in coastal wetlands: methodological aspects. Hydrobiologa 269-270, pp.

Wang, K., Hu, Y., and He, J., 2012. Deformation cycles of subduction earthquakes in a viscoelastic Earth. Nature, 484 (7394), 327-332.

Wang, P. L., Engelhart, S. E., Wang, K., Hawkes, A. D., Horton, B. P., Nelson, A. R., Witter, R. C., 2013. Heterogeneous rupture in the great Cascadia earthquake of 1700 inferred from coastal subsidence estimates. Journal of Geophysical Research: Solid Earth, 118(5), 24602473 .

Watcham, E.P., Shennan, I., Barlow, N.L.M., 2013. Scale considerations in using diatoms as indicators of sea-level change: lessons from Alaska. Quaternary Science Reviews 28, 165179.

Whiting, M. C., Mcintire, C. D., 1985. An investigation of distributional patterns in the diatom flora of Netarts Bay, Oregon, by correspondence analysis1. Journal of Phycology, 21, 655661.

Williams, H., Hutchinson, I., 2000. Stratigraphic and microfossil evidence for late Holocene tsunamis at Swantown marsh, Whidbey Island, Washington. Quaternary Research, 54(2), 218-227.

Williams, H.F., Hutchinson, I., Nelson, A.R., 2005. Multiple sources for late-Holocene tsunamis at Discovery Bay, Washington State, USA. The Holocene, 15, 60-73.

Wilson, G. P., Lamb, A. L., 2012. An assessment of the utility of regional diatom-based tidallevel transfer functions. Journal of Quaternary Science,27(4), 360-370. 
1316

1317

1318

1319

1320

1321

1322

1323

1324

1325

1326

1327

1328

1329

1330

1331

1332

1333

1334

1335

1336

1337

1338

1339

1340

1341

1342

1343

1344

1345

1346

1347

1348

1349

1350

1351

1352

1353

1354

1355

1356

1357

1358

1359

1360

1361

1362

1363

1364

1365
Wilson, R., Hemphill-Haley, E., Jaffe, B., Richmond, B., Peters, R., Graehl, N., Kelsey, H., Leeper, R., Watt, S., McGann, M., Hoirup, D., Chague-Goff, C., Goff, J., Caldwell, D., Loofbourrow, C., 2014. The search for geologic evidence of distant-source tsunamis using new field data in California, chap. C of Ross, S.L., and Jones, L.M., eds., The SAFRR (Science Application for Risk Reduction) tsunami scenario: U.S. Geological Survey OpenFile Report 2013-1170, 214 p., http://dx.doi./of/20131170/c/.

Witter, R.C., Kelsey, H.M., Hemphill-Haley, E., 2001. Pacific storms, El Nino and tsunamis: competing mechanisms for sand deposition in a coastal marsh, Euchre Creek, Oregon. J. Coast. Res. 563-583.

Witter, R.C., Kelsey, H.M., Hemphill-Haley, E., 2003. Great Cascadia earthquakes and tsunamis of the past 6700 years, Coquille River estuary, southern coastal Oregon. Geological Society of America Bulletin 115,1289-1306.

Witter, R. C., Hemphill-Haley, E., Hart, R., Gay, L., 2009. Tracking Prehistoric Cascadia Tsunami Deposits at Nestucca Bay, Oregon. US Geological Survey, National Earthquake Hazards Reduction Program Final Technical Report 08HQGR0076, 92.

Woodruff, J.D., Donnelly, J.P., Okusu, A., 2009. Exploring typhoon variability over the mid-tolate Holocene: evidence of extreme coastal flooding from Kamikoshiki, Japan. Quaternary Science Reviews 28, 1774-1785.

Woodroffe, S.A., Long, A.J., 2010. Reconstructing recent relative sea-level changes in West Greenland: Local diatom-based transfer functions are superior to regional models. Quaternary International, 221, 91-103.

Wright, C., and Mella, A., 1963. Modifications to the soil pattern of South-Central Chile resulting from seismic and associated phenomenona during the period May to August 1960. Bulletin of the Seismological Society of America, 53(6), 1367-1402.

Yeats, R.S., Sieh, K.E., Allen, C.R., 1997. The geology of earthquakes. Oxford University Press, Oxford, $568 \mathrm{pp}$.

Yoshida, T. Jogan Ju'uichi Nen Mutsu Fujou no Shindou Kouitsu [Quake and flood in 11th year of Jogan era] Rekishi Chiri 8, 1033-1040 (1906) [in Japanese]

Zong, Y.Q., Tooley, M.J., 1996. Holocene sea-level changes and crustal movements in Morecambe Bay, northwest England. Journal of Quaternary Science 11, 43-58.

Zong, Y., 1997. Implications of Paralia sulcata abundance in Scottish isolation basins. Diatom Research, 12, 125-150.

Zong, Y., Horton, B. P., 1998. Diatom zones across intertidal flats and coastal saltmarshes in Britain. Diatom Research, 13, 375-394.

Zong, Y.Q., Horton, B.P., 1999. Diatom-based tidal-level transfer functions as an aid in reconstructing Quaternary history of sea-level movements in the UK. Journal of Quaternary Science, 14, 153-167. 
Zong, Y.Q., Shennan, I., Combellick, R.A., Hamilton, S.L., Rutherford, M.M., 2003. Microfossil

\section{Figure captions}

1371 Figure 1: Schematic drawing of coseismic uplift (a) and subsidence (b) and 1372 accompanying tsunami inundation.

1374 Figure 2: Summary of earthquake and tsunami studies applying diatoms that are 1375 referenced in this paper, and listed in Table 1. (a) In: Indian Ocean; (b) Ja: Japan Trench;

1376 (c) Al: Alaska-Aleutian megathrust; (d) Ca: Cascadia subduction zone; (e) Ch: Chilean

1377 Subduction zone; (f) NZ: New Zealand; NS: North Sea (studies marked with an asterisk 1378 because they are not subduction zone studies); SP: South Pacific; PNG: Papua New 1379 Guinea.

1381 Figure 3: Qualitative schematic of the distribution of common diatom species along a 1382 modern salt marsh transect. Typical salinity classes (following the halobian classification 1383 scheme of Hemphill-Haley, 1993) for each environment are shown.

1385 Figure 4: Diatoms evaluated relative to modern intertidal zones and stratigraphy at the 1386 Niawiakum River in Washington State, USA. (a) Position of the study area relative to the 1387 Cascadia subduction zone (barbed line), the boundary between North America and Juan 1388 de Fuca/Gorda plates that extends from the northern end of the San Andreas Fault (SAF) 1389 to the southern end of the Queen Charlotte Fault (QCF); (b) Location of the Niawiakum 1390 River Valley, on the eastern side of Willapa Bay; (c) Locations of vertical sections 
1391 sampled for diatoms in the Niawiakum River Valley. Sites 1-4 are cutbank outcrops

1392 exposed during low tide; (d) Changes in diatom assemblages within and above a former

1393 upland soil (forming at the transition of extreme high water (EHW) and upland) buried by

1394 coseismic subsidence during a Cascadia subduction zone earthquake in AD 1700.

1395 Changes in diatom assemblages are consistent with an abrupt change from upland forest

1396 to tidal flat or low marsh. (Modified from Hemphill-Haley, 1995a).

1398 Figure 5: Diatom analyses during past earthquake cycles on the Alaska-Aleutian 1399 megathrust suggesting preseismic movement. (a) Location of south-central Alaska, USA; 1400 (b) area subsided in the AD 1964 earthquake (Plafker, 1969); (c) Relative sea level (RSL) 1401 changes reconstructed using a diatom-based transfer function; two short periods of 1402 preseismic submergence immediately prior to substantial coseismic subsidence were 1403 recognized at the top of peat units and are highlighted with red arrows. (Modified and 1404 reprinted from Shennan, I., Hamilton, S., Coseismic and preseismic subsidence 1405 associated with great earthquakes in Alaska. Quaternary Science Reviews 25, 1-8, 2006, 1406 with permission from Elsevier).

1408 Figure 6: Example of land-level reconstructions using diatoms in Hokkaido, northern 1409 Japan. (a) Position of study area relative to the Kurile Trench. The solid line with 1410 triangles shows the seaward edge of the subduction zone. The volcanoes responsible for 1411 tephra layers in $\mathrm{c}$ and $\mathrm{d}$ are shown and rupture areas of instrumentally recorded 1412 earthquakes on the plate boundary off eastern Hokkaido are outlined; (b) Map of 1413 Mochirippu Estuary showing location of stratigraphic cross-section; (c) Stratigraphic 
1414 cross-section; (d) Photograph and log of stratigraphy. Example of change from tidal-flat

1415 mud to lowland-forest peat, punctuated by a tsunami deposit and by volcanic ash layers.

1416 (e) Diatom diagram showing the schematic stratigraphy, changes in diatom assemblages,

1417 and the results of diatom-based transfer functions showing the seventeenth-century large

1418 earthquake. Error bars for height estimates span two standard deviations. (Modified and

1419 reprinted from Sawai, Y., Satake, K., Takanobu, K., Nasu, H., Shishikura, M., Atwater,

1420 B.F., Horton, B.P., Kelsey, H.M., Nagumo, T., Yamaguchi, M., Transient uplift after a

$142117^{\text {th }}$-century earthquake along the Kuril subduction zone. Science 306, 1918-1920, 2006,

1422 with permission from The American Association for the Advancement of Science).

1424 Figure 7: Diatom analyses of the Storegga Slide tsunami showing fragmentation of 1425 diatom valves within the high-energy deposit. (a) Location of the Storegga Slides and 1426 sites where evidence for the Holocene Storegga Slide tsunami has been found; (b) Sites in 1427 the United Kingdom where evidence for the Holocene Storegga Slide tsunami may be 1428 found. Numbers correspond to sites discussed in Smith et al., 2004; (c) Diatom summary 1429 diagram from Boreholes 53 and 23 in lower Wick River Valley, Caithness, Scotland 1430 (Dawson et al., 1996). Taxa displayed as \% of total valves. (Modified and reprinted from 1431 Smith, D.E., Shi, S., Cullingford, R.A., Dawson, A.G., Dawson, S., Firth, C.R., Foster, 1432 I.D.L., Fretwell, P.T., Haggart, B.A., Holloway, L.K., Long, D., The Holocene Storegga 1433 slide tsunami in the United Kingdom. Quaternary Science Reviews 23, 2291-2321, 2004, 1434 and Dawson, S., Smith, D.E., Ruffman, A., Shi, S., The diatom biostratigraphy of 1435 tsunami deposits: Examples from recent and middle Holocene events. Physics and 1436 Chemistry of the Earth, 21, 87-92, 1996, with permission from Elsevier). 
1438 Figure 8: Diatom analyses of the 2004 Indian Ocean tsunami deposit showing grading of

1439 diatom valves; (a) Position of study area relative to the Sunda Trench. Fault slip during

1440 the 2004 Sumatra-Andaman earthquake (Chlieh et al., 2007); (b) Phra Thong Island. The

1441 island is isolated from the mainland of Thailand by inlets. Light gray area is grassy beach

1442 ridge plains. Dark gray area is mangrove forests. Landforms traced from 1:50,000-scale

1443 airphotos taken in 1999 and from post-tsunami satellite images at PointAsia.com

1444 (modified from Jankaew et al., 2008); (c) Location of pit and modern samples. Satellite

1445 image is from PointAsia.com; (d) Diatom diagram showing the schematic stratigraphy of

1446 location 6 and changes in diatom assemblages throughout the 2004 tsunami deposit.

1447 Abundant beach and subtidal species are more abundant in the bottom of the sand bed 1448 and freshwater diatoms become more abundant in the top of the sand bed. Diatom valves 1449 are relatively pristine in the tsunami deposit as shown by the high percentage of unbroken 1450 valves. (e) Simplified process of deposition of diatoms and sediment during tsunami; (1)

1451 Fast current. Only beach and subtidal species are incorporated with coarse sediment.

1452 Because turbulent current can keep a substantial amount of sand fraction in the water 1453 column, mixed assemblages of many beach and subtidal, marine plankton are suspended.

1454 Freshwater specimens may be included with eroded soil fractions. (2) Current becomes 1455 slow. Fine fractions fall onto the ground. Eroded, floated, and transported specimens are 1456 also incorporated. (3) Suspension stage (calm current) of tsunami. All floated specimens 1457 are allowed to settle down. Many freshwater species incorporated with their substrata 1458 (plant trash and eroded soil fractions). (Modified and reprinted from Sawai, Y., Jankaew, 1459 K., Martin, M.E., Prendergast, A., Choowong, M., Charoentitirat, T., Diatom 
1460 assemblages in tsunami deposits associated with the 2004 Indian Ocean tsunami at Phra

1461 Thong Island, Thailand. Marine Micropaleontology, 73, 70-79, 2009, with permission 1462 from Elsevier).

1463 


\section{During \\ Earthquake}

3 Decades to centuries later

\section{Coseismic}

uplift

(b)

Coseismic

subsidence
Tidal flat deposit

Sea level

(MTL)

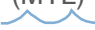

(

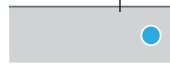

High

marsh

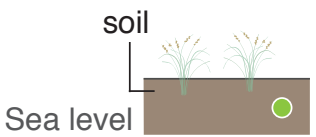

(MTL)
High marsh deposit

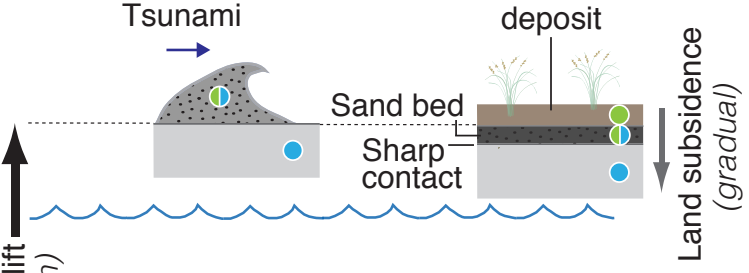

- Marine/brackish diatom assemblage

- Mixed diatom assemblage

- Diatom assemblage reflecting increased freshwater influence

Tidal flat deposit

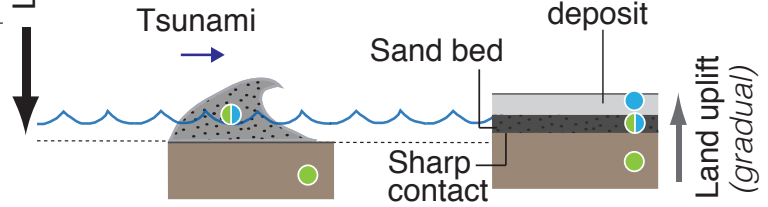


Aulacoseira crassipunctata

\section{Halophobous}

Eunotia bilunaris

Diadesmis contenta

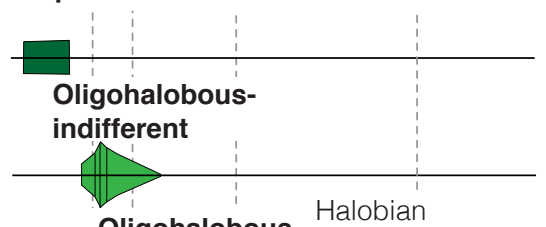

Denticula subtilis

Cosmioneis pusilla Pinnularia lagerstedtii

Caloneis bacillum Frustulia vulgaris Luticola mutica Tryblionella debilis

Amphora salina Scolioneis tumida Tryblionella granulata Rhopalodia musculus

Diploneis decipiens var. parallela Planothidium delicatulum _

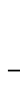

Oligohaloboushalophile

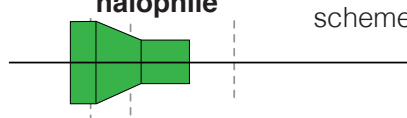

\section{Mesohalobous}

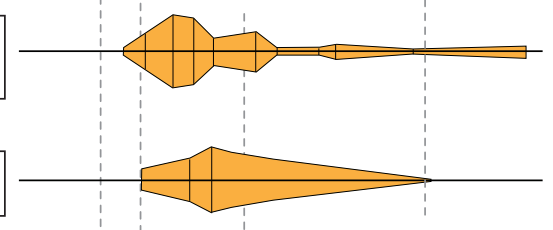

\section{Polyhalobous}

Achnanthes brevipes Cocconeis scutellum Tabularia fasciculata

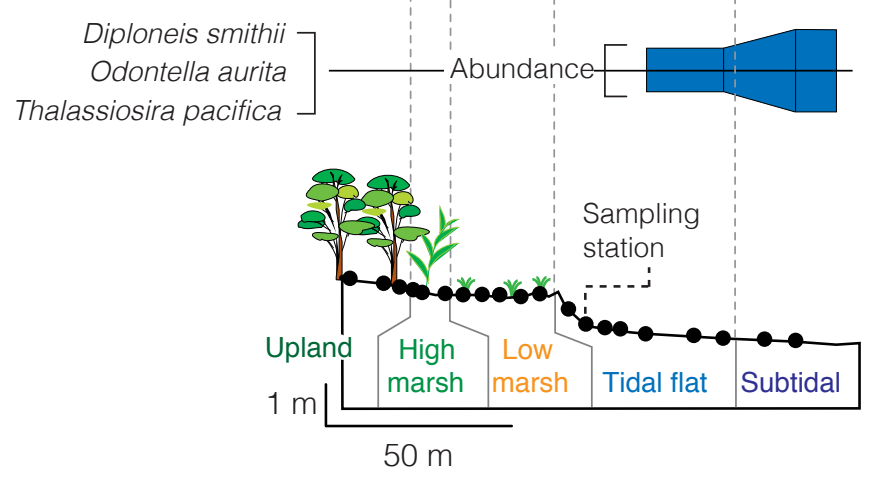

Diploneis smithii Odontella aurita Thalassiosira pacifica 


\section{Figure 4}

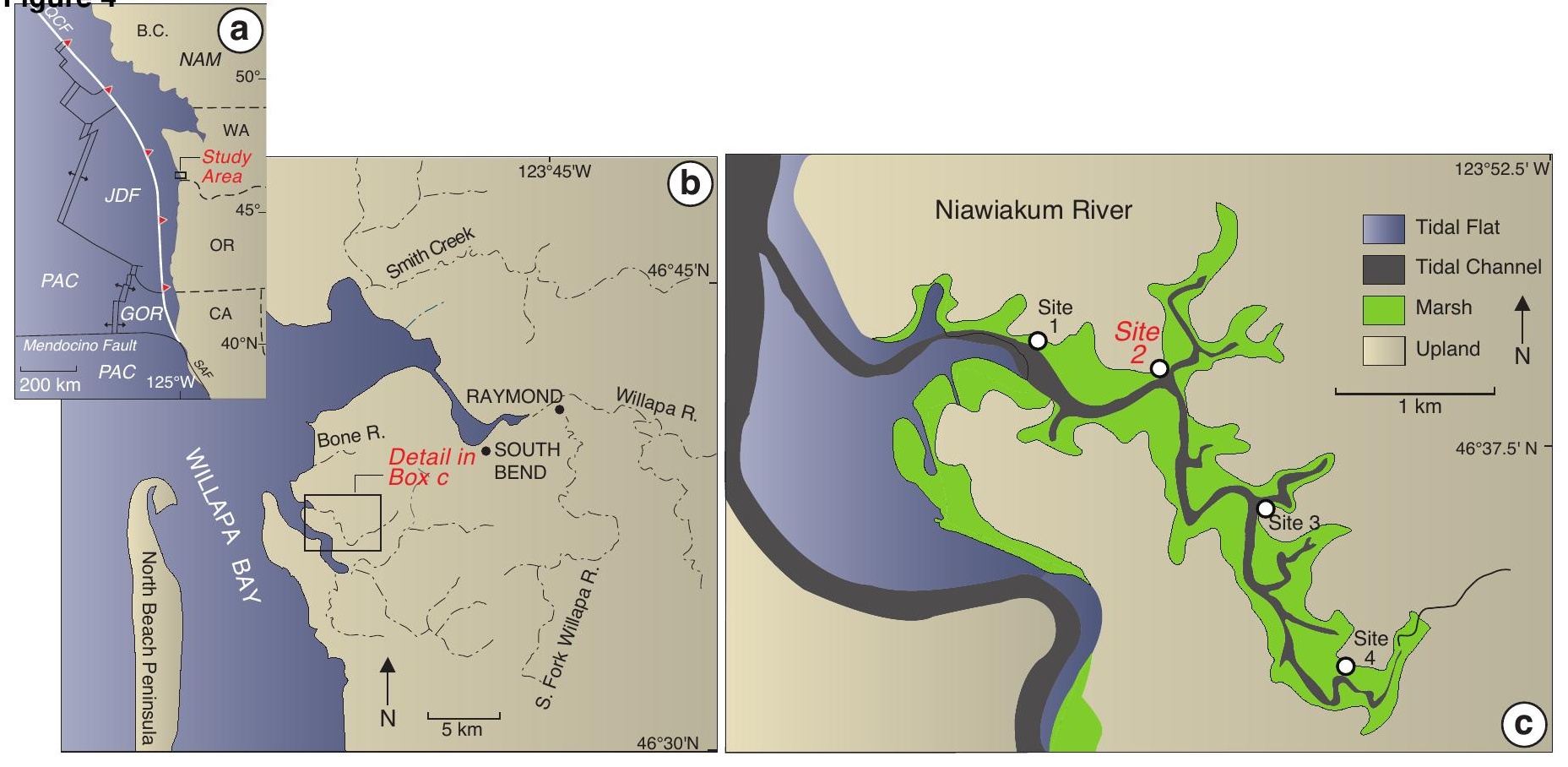

(d)

Site 2
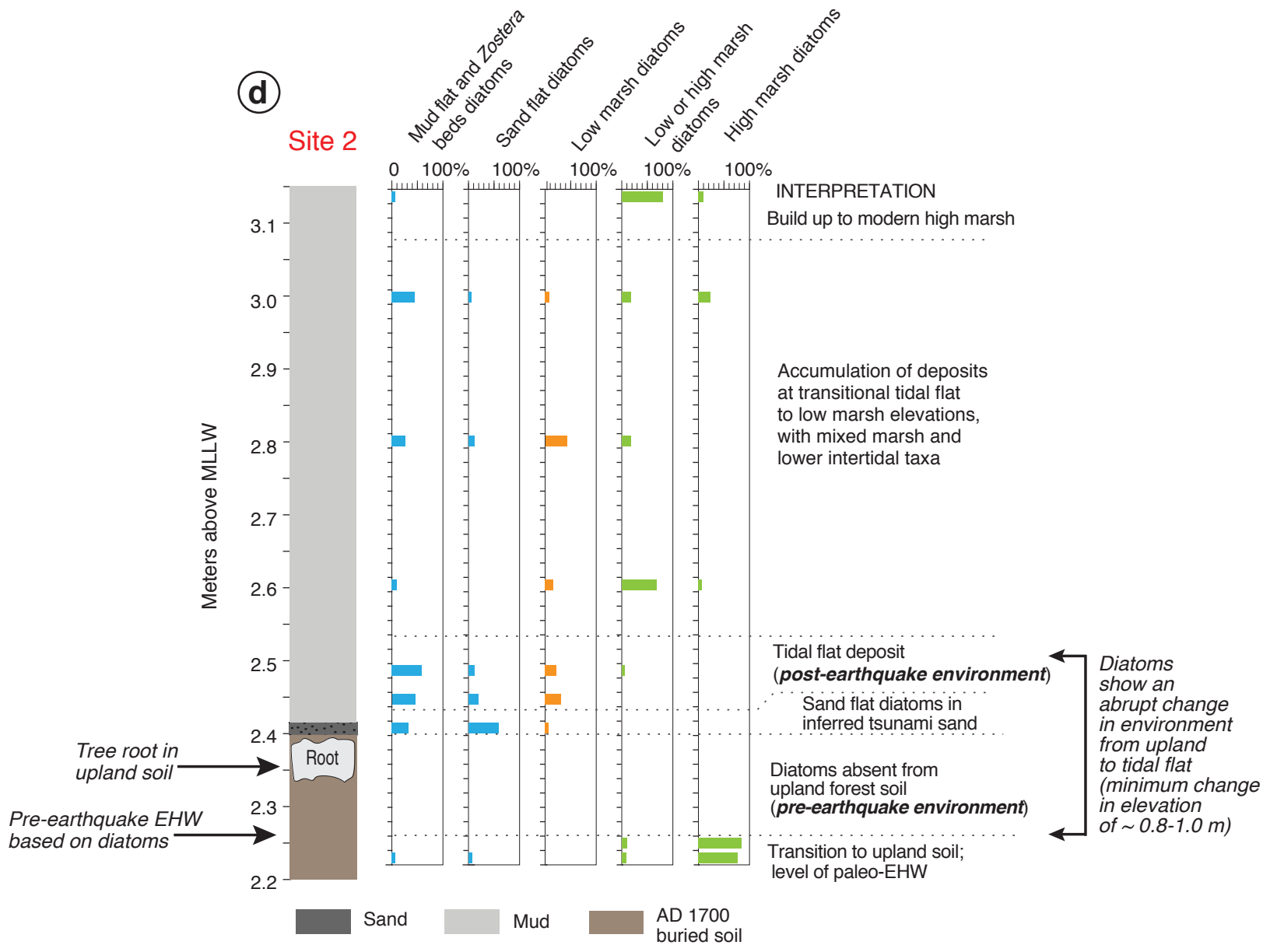


\section{Figure 6}
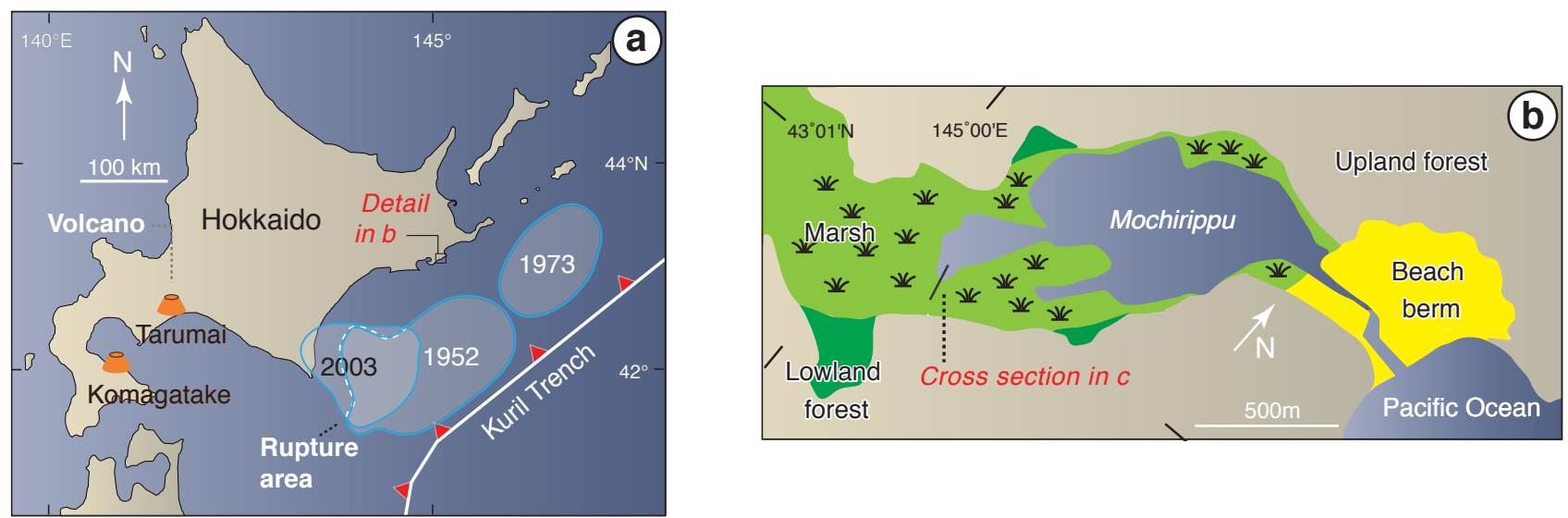

(c)

\section{South}

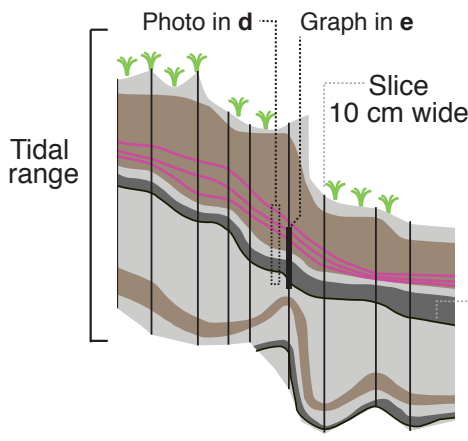

North

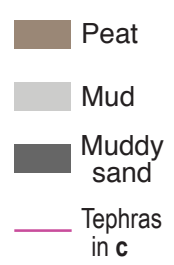

Sharp contact (<2 mm)

$$
\frac{10 \mathrm{~cm}}{50 \mathrm{~m}}
$$

(d)

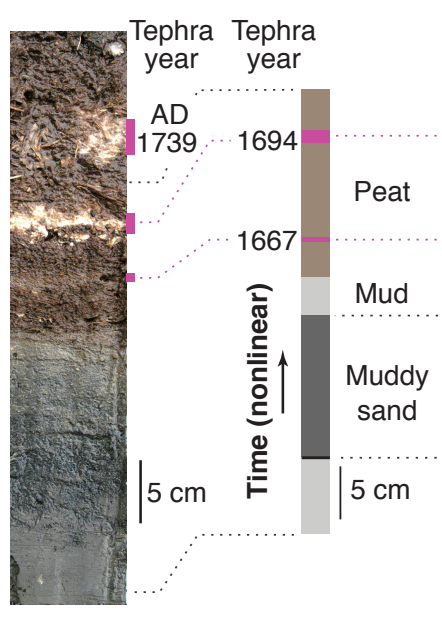

(e)

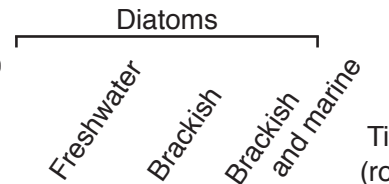

(rotated $90^{\circ}$ )

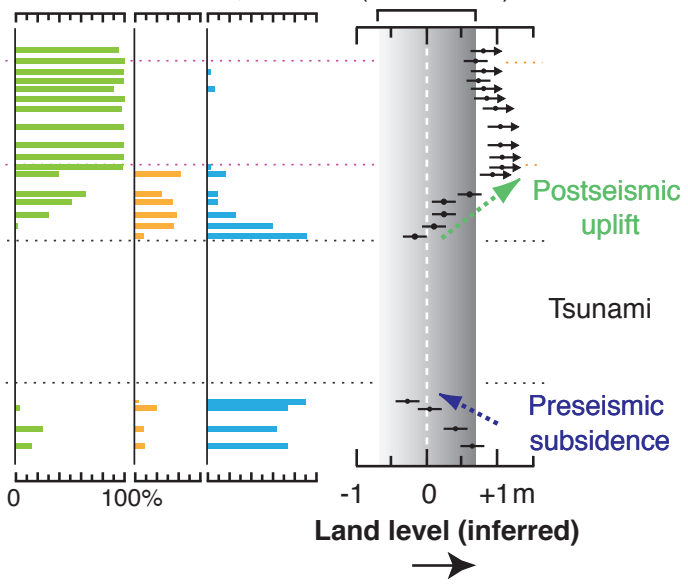



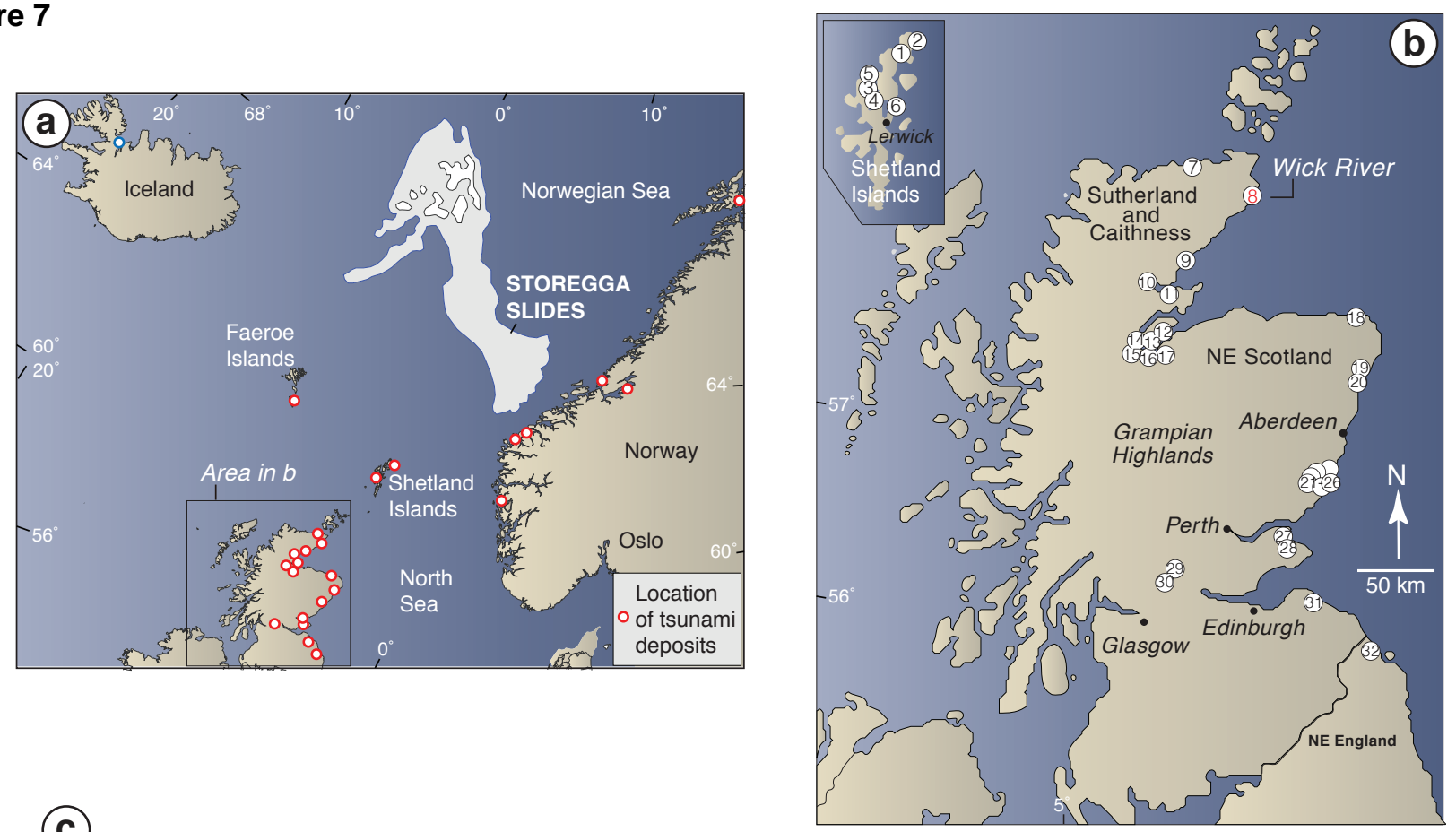

(c)

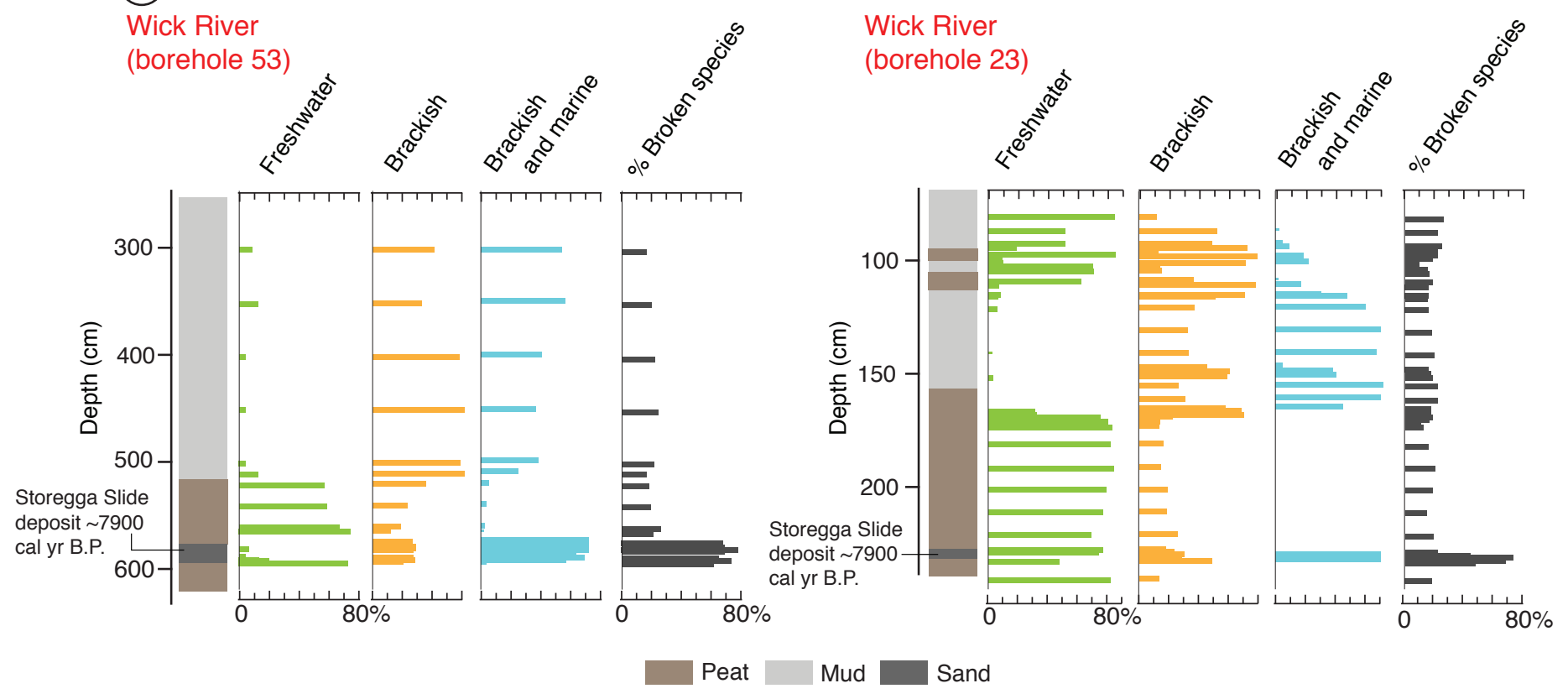


Figure 8
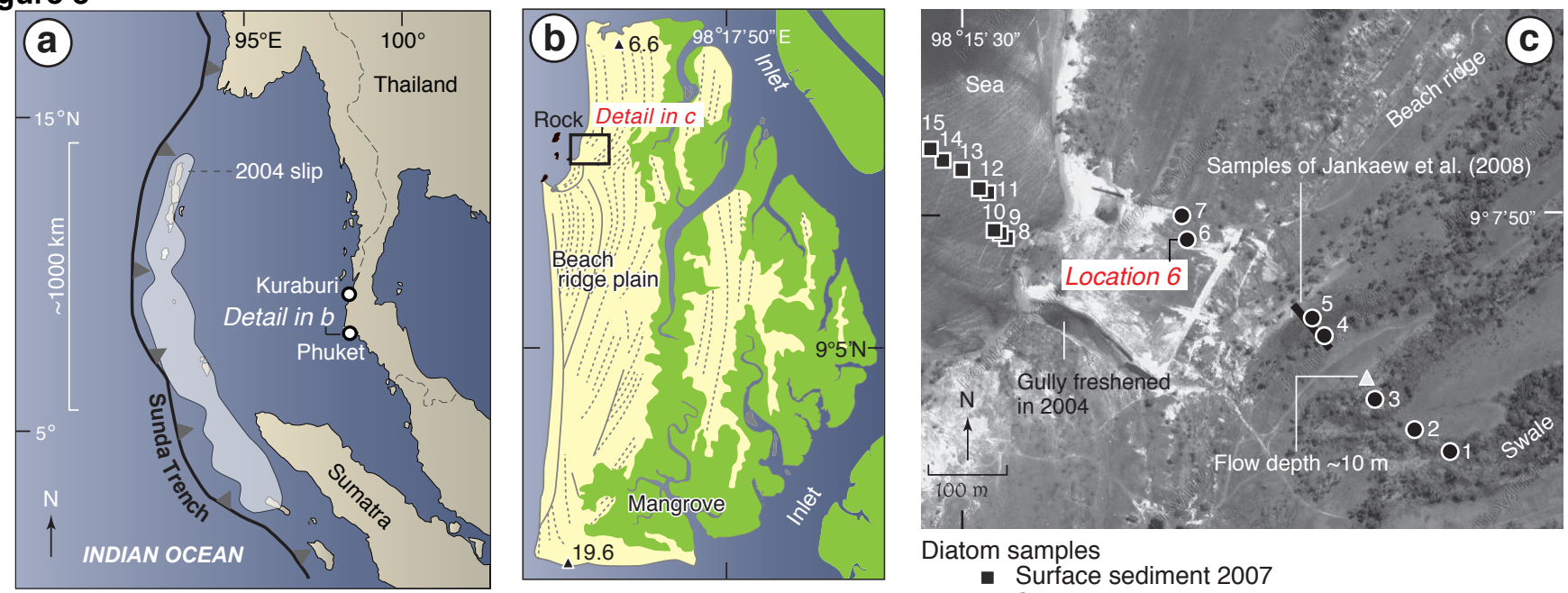

Diatom samples

- Surface sediment 2007

- Surface sediment 2007 and tsunami deposit 2004

(d)

Location 6 Benthic
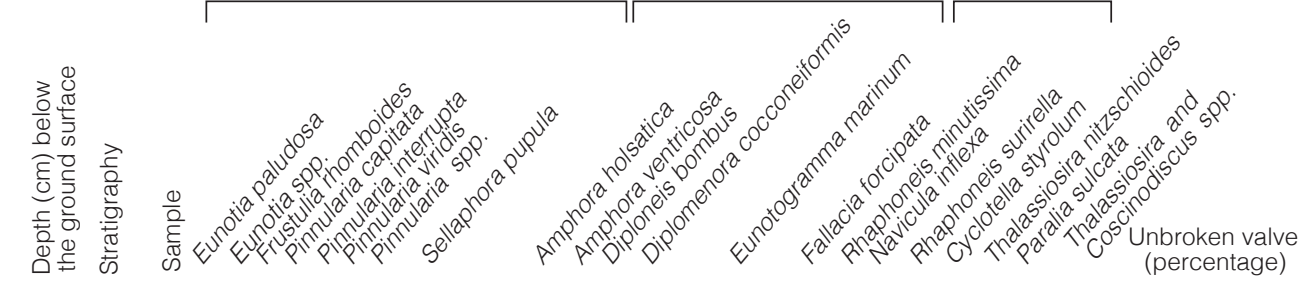

0
-10
$10-$
$20-$

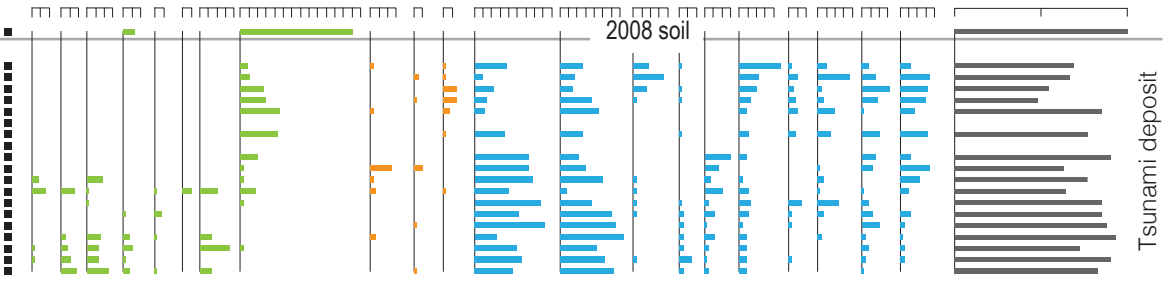

$$
\text { 눈 }
$$

$100 \%$

fmc

\begin{tabular}{|c|c|c|c|c|}
\hline & Peat & 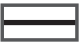 & Sharp contact & \multirow{4}{*}{$\begin{array}{l}\text { Grain size } \\
\text { of sand finc...... Medine }\end{array}$} \\
\hline & Mud & 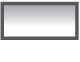 & Gradual contact & \\
\hline$\because \because$ & $\begin{array}{l}\text { Muddy sand } \\
\text { or sandy mud }\end{array}$ & $\infty$ & Rhizome & \\
\hline$\because \because \because 6]$ & Sand & $\approx$ & Laminae & \\
\hline
\end{tabular}

(e)

(1)

(2)
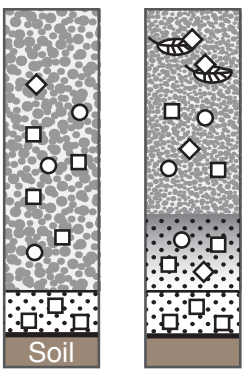

(3)

Diatoms

$\diamond$ Freshwater species

口 Beach and subtidal species

- Marine plankton

Sediment

Plant trash

$\square$ Mud

$\because \because$ Muddy sand

$\because$ Sand

Inferred flow velocity

Fast

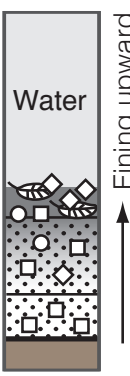

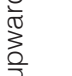

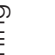

(1)

(1)

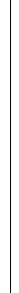


Table 1. A global database of subduction zone earthquake and tsunami studies that have employed diatoms

\begin{tabular}{|c|c|c|c|c|c|c|}
\hline $\begin{array}{l}\text { Map } \\
\text { code }\end{array}$ & $\begin{array}{l}\text { Earthquake and tsunami studies } \\
\text { employing diatoms }\end{array}$ & $\begin{array}{l}\text { Dratom evidence tor } \\
\text { coseismic land-level change }\end{array}$ & $\begin{array}{l}\text { Accompranying } \\
\text { tsunami }^{2}\end{array}$ & $\begin{array}{l}\text { of tsunami deposit } \\
\text { of }^{3}\end{array}$ & $\begin{array}{l}\text { Preservationor } \\
\text { diatom valves }\end{array}$ & $\begin{array}{l}\text { Concentratrolior } \\
\text { diatom valves } 5\end{array}$ \\
\hline & Alaska & & & & & \\
\hline Al-1 & Shennan et al., 1999 & Yes (H, Qn) & -- & -- & -- & -- \\
\hline Al-2 & Zong et al., 2003 & Yes $(H, Q n)$ & -- & -- & -- & -- \\
\hline Al-3 & Hamilton et al., 2005 & Yes $(H, P, Q n)$ & -- & -- & -- & -- \\
\hline Al-4 & Hamilton and Shennan, 2005a & Yes $(H, P, Q n)$ & -- & -- & -- & -- \\
\hline Al-5 & Hamilton and Shennan, 2005b & Yes $(H, P, Q n)$ & -- & -- & -- & -- \\
\hline Al-6 & Shennan and Hamilton, 2006 & Yes (H, P, Qn) & -- & -- & -- & -- \\
\hline Al-7 & Watcham et al., 2013 & Yes (H, P, Qn) & -- & -- & -- & -- \\
\hline Al-8 & Shennan et al., 2009 & Yes (H, P, Ql) & -- & -- & -- & -- \\
\hline Al-9 & Shennan et al., 2014a & Yes (H, P, Qn) & -- & -- & -- & -- \\
\hline Al-10 & Shennan et al., 2014b & Yes (H, P, Qn) & -- & -- & -- & -- \\
\hline Al-11 & Briggs et al., 2014 & Yes (H, P, Ql) & Yes & Mx & Good & High \\
\hline \multirow[t]{2}{*}{ Al-12 } & Nelson et al.,2015 & No & Yes $(H, P)$ & Fw & Poor & Low \\
\hline & Cascadia & & & & & \\
\hline $\mathrm{Ca}-1$ & Darienzo and Peterson, 1990 & Yes (P, Ql) & Yes $(P)$ & $M \& B$ & -- & -- \\
\hline $\mathrm{Ca}-2$ & Darienzo et al., 1994 & Yes (P, Ql) & Yes $(P)$ & $M \& B$ & -- & -- \\
\hline Ca-3 & Hemphill-Haley, 1995a & Yes (P, Ql) & Yes $(P)$ & M\&B (Ep) & Very good & -- \\
\hline $\mathrm{Ca}-4$ & Hemphill-Haley, 1996 & Yes (P, Ql) & Yes $(P)$ & $\mathrm{M} \& B(E p, P I)$ & Very good & High \\
\hline Ca-5 & Shennan et al., 1996 & Yes $(P, Q n)$ & Yes $(P)$ & M\&B (Ep) & -- & -- \\
\hline Ca-6 & Nelson et al., 1996b & Yes $(P, Q n)$ & No & -- & -- & -- \\
\hline $\mathrm{Ca}-7$ & Atwater and Hemphill-Haley, 1997 & Yes (P, Ql) & Yes $(P)$ & $M \& B(E p)$ & Very good & -- \\
\hline Ca-8 & Benson et al., 1997 & No & Yes $(H, P)$ & M & -- & -- \\
\hline Ca-9 & Hutchinson et al., 1997 & No & Yes $(P)$ & $M \& B(E p)$ & -- & -- \\
\hline Ca-10 & Clague et al., 1999 & Yes (P, Ql) & Yes $(P)$ & M\&B & Good & -- \\
\hline Ca-11 & Hutchinson et al., 2000 & Yes (P, Ql) & Yes $(P)$ & $\mathrm{Mx}$ & Good & Low \\
\hline $\mathrm{Ca}-12$ & Sherrod et al., 2000 & Yes $(P)$ & No & -- & -- & -- \\
\hline Ca-13 & Williams and Hutchinson, 2000 & No & Yes $(P)$ & $M \& B$ & Poor & Low \\
\hline Ca-14 & Sherrod, 2001 & Yes (P, Ql) & No & -- & -- & -- \\
\hline Ca-15 & Kelsey et al., 2002 & Yes (P, Ql) & Yes $(P)$ & M\&B (Ep?) & Good & Low \\
\hline Ca-16 & Kelsey et al., 2004 & Yes (P, Ql) & No & -- & -- & -- \\
\hline Ca-17 & Witter et al., 2003 & Yes (P, Ql) & Yes $(P)$ & M (Ep) & -- & Low \\
\hline Ca-18 & Kelsey et al., 2005 & No & Yes $(P)$ & few $M$ & -- & Low \\
\hline Ca-19 & Williams et al., 2005 & Yes (P, Ql) & Yes $(P)$ & $\mathrm{M}(\mathrm{Ep}, \mathrm{Pl})$ & Good & High \\
\hline $\mathrm{Ca}-20$ & Nelson et al., 2008 & Yes (P, Qn) & Yes $(P)$ & $\mathrm{M} \& \mathrm{~B}(\mathrm{Ep}, \mathrm{PI})$ & -- & Low \\
\hline Ca-21 & Witter et al., 2009 & Yes (P, Ql) & Yes $(P)$ & M (Ep) & Poor & High \\
\hline Ca-22 & Peterson et al., 2011 & No & Yes $(P)$ & $M \& B$ & -- & -- \\
\hline $\mathrm{Ca}-23$ & Graehl et al., 2014 & Yes (P, Ql) & Yes $(P)$ & M\&B (Ep) & Good & Low \\
\hline \multirow[t]{2}{*}{ Ca-24 } & Wilson et al., 2014 & Yes (P, Ql) & Yes $(H, P)$ & $\mathrm{Mx}(\mathrm{PI}, \mathrm{G})$ & Good & High \\
\hline & Chile & & & & & \\
\hline Ch-1 & Cisternas et al., 2005 & Yes (H, P, Ql) & Yes $(H, P)$ & -- & -- & -- \\
\hline Ch-2 & Nelson et al., 2009 & Yes (H, P, Qn) & Yes (P) & $M x$ & -- & -- \\
\hline Ch-3 & Horton et al., 2011 & No & Yes $(H)$ & $\mathrm{M} \& \mathrm{~B}(\mathrm{Ep}, \mathrm{Pl})$ & Selective & High \\
\hline Ch-4 & Garrett et al., 2013 & Yes $(H, Q n)$ & Yes $(H)$ & $M x(E p)$ & -- & -- \\
\hline Ch-5 & Dura et al., 2014 & Yes (P, Ql) & Yes $(P)$ & $\mathrm{M} \& \mathrm{~B}(\mathrm{PI}, \mathrm{G})$ & Poor & Low \\
\hline Ch-6 & Garrett et al., 2014 & Yes (H, P, Qn) & Yes $(H, P)$ & M\&B (Ep) & -- & -- \\
\hline \multirow[t]{2}{*}{ Ch-7 } & Chagué-Goff et al., 2015 & No & Yes $(\mathrm{H})$ & $M \& B$ & Poor & Low \\
\hline & Indian Ocean & & & & & \\
\hline In-1 & Jankaew et al., 2008 & No & Yes $(H, P)$ & M\&B & Good $(\mathrm{H}) /$ Poor $(\mathrm{P})$ & $\operatorname{High}(\mathrm{H}) / \operatorname{Low}(\mathrm{P})$ \\
\hline In-2 & Monecke et al., 2008 & No & Yes $(H, P)$ & Fw\&B & Good $(H) /$ Poor $(P)$ & High $(\mathrm{H}) /$ Low $(\mathrm{P})$ \\
\hline In-3 & Sawai et al., 2009a & No & Yes $(\mathrm{H})$ & $\mathrm{Mx}(\mathrm{PI}, \mathrm{G})$ & Good & -- \\
\hline In-4 & Kokociński et al., 2009 & No & Yes $(H)$ & $\mathrm{Mx}(\mathrm{Ep}, \mathrm{PI})$ & Poor & Low \\
\hline
\end{tabular}

